\title{
What Developments in Western Europe Tell Us about American Critiques of Corporate Criminal Liability $\dagger$
}

\author{
Sara Sun Beale $\dagger \dagger$ and Adam G. Safwat $+\uparrow \dagger$
}

Although corporate criminal liability has been recognized in the United States for nearly a century, ${ }_{1}$ contemporary academic commentators have questioned its legitimacy and argued that it is inferior to its alternatives: civil liability for the corporation and/or criminal liability for individual corporate agents. Other academic critics have attacked the present definitions of corporate criminal liability. ${ }^{2}$ In other words, although corporate criminal

$\dagger$ The authors would like to express their thanks to Katherine Topulos, Foreign and International Law Librarian, Duke University, for invaluable assistance in identifying and locating source materials on European law, and to Scott Edson, Christopher Kocher, Johanna Stein, Megan Walsh, and Bryan Wilson at Duke Law School for their research assistance. Francesca Bignami, James Cox, Deborah DeMott, and Ralf Michaels provided helpful comments on many topics. We benefitted from the advice of Sharon Byrd, Markus Dubber, and Konstantinos Papageorgiou regarding German approaches to the function of criminal law. We thank Nis Clausen and Thomas Elholm for their insights into Danish and EU law, and Robert Roth for insights into Swiss law. Finally, the authors would like to thank Marie-Christine Monsallier-Saint Mleux for her insights into French law. Any errors contained herein are solely the responsibility of the authors.

$\dagger$ Charles L.B. Lowndes Professor of Law, Duke University.

†† J.D., LL.M., 1994, Duke Law School. Assistant United States Attorney, District of Delaware. The views and opinions expressed here are solely those of the authors and do not necessarily represent those of the U.S. Department of Justice.

1. The seminal case recognizing corporate criminal liability is New York Central \& Hudson River R.R. Co. v. United States, 212 U.S. 481 (1909). For a general discussion of the history of corporate criminal liability in the United States, see Kathleen F. Brickey, Corporate Criminal Liability § 1:01-1:19 (2d ed. 1992), and 1 Sarah N. Welling, Sara Sun Beale, \& Pamela H. Bucy, Federal Criminal Law and Related Actions: Crimes, Forfeiture, the False Claims Act and Rico $\$ 5.2$ (1998).

2. For examples of influential proposals to restrict or reframe the scope of respondeat superior liability, see Model Penal Code $§ 2.07(1)(c)$ (Proposed Official Draft 1962) \& cmt. 2(c) (Official Draft and Revised Comments 1985) (restricting corporate liability to criminal conduct performed, participated in, or recklessly tolerated by the board of directors or corporate officers or agents whose positions in the corporate hierarchy are high enough that they may reasonably be deemed 
liability has also had its academic champions, it has been under attack in the United States. The situation in Europe poses a sharp contrast. Europe does not have a long history of recognizing corporate criminal liability. In the last quarter of the twentieth century, however, many Western European nations have created criminal liability for corporations. The juxtaposition of these European and American trends raises the question we wish to explore: if corporate criminal liability is so controversial in the United States, why are many Western European countries creating or expanding the criminal liability of corporations? Or, to turn the question around, what can we learn from the European experience that might shed light on the academic dispute in the United States about the justifications for imposing criminal liability on corporations? ${ }^{3}$

This debate takes on added significance in view of the remarkable litany of corporate misconduct that has come to

to have the authority to set policy for the corporation); Jennifer Arlen, The Potentially Perverse Effects of Corporate Criminal Liability, 23 J. Legal Stud. 833, 848-49 (1994) (arguing that a strict regime of vicarious corporate liability can have the perverse effect of discouraging socially desirable corporate monitoring); Pamela H. Bucy, Corporate Ethos: A Standard for Corporate Criminal Liability, 75 Minn. L. Rev. 1095, 1099 (1991) (proposing that corporate liability be based upon corporate "ethos," or personality, in order to limit criminal liability to cases where the criminal conduct in question is consistent with corporate goals, policies, and ethos, rather than the result of actions by one or two maverick employees); Jennifer Arlen \& Reinier Kraakman, Controlling Corporate Misconduct: An Analysis of Corporate Liability Regimes, 72 N.Y.U. L. Rev. 687, 736 (1997) (arguing in favor of imposing high sanctions based on vicarious liability but mitigating those sanctions based upon the corporation's compliance activities). The United States Sentencing Commission has proposed a major revision of the corporate sentencing guidelines that may be seen as a response to these critiques. Amendments to the Sentencing Guidelines, Effective Compliance and Ethics Programs in Chapter Eight, 69 Fed. Reg. 28994, 29018-25, (§ 8B2.1, § 8C2.5(g) $\S 8 \mathrm{C} 2.5(\mathrm{f}), \S 8 \mathrm{D} 1.4(\mathrm{c}), \S 8 \mathrm{~F} 1.1$ ) (proposed April 30, 2004), available at http://www.ussc.gov/2004guid/2004cong.pdf. These Amendments will be effective in November 2004 unless Congress intervenes.

3. For a sobering description of the difficulties that attend all comparative analyses, see Jonathan B. Wiener, Whose Precaution After All? A Comment on the Comparison and Evolution of Risk Regulatory Systems, 13 Duke J. Comp. \& Int'l L. 207, 248-53 (2003); see also Herbert L. Bernstein, Whose Advantage After All? A Comment on the Comparison of Civil Justice Systems, 21 U.C. Davis L. Rev. 587 (1988). 
light in both the U.S. and Europe in recent years. Following the 1990s, a decade that saw a wave of antitrust, environmental, and fraud prosecutions of major corporations, ${ }^{4}$ the new century began with a series of corporate accounting scandals that rocked the stock markets, destroyed billions in equity, and caused the loss of tens, if not hundreds, of thousands of jobs. In the United States, the most prominent example was Enron (formerly the seventh most valuable company in the United States), ${ }^{5}$ which has lost approximately $\$ 100$ billion in shareholder equity $^{6}$ and eventually filed for bankruptcy after the revelation that it had systematically used special purpose entities to shift debt off its books and hide corporate losses. ${ }^{7}$ As of July 2004, thirty-one persons connected to Enron had been indicted, and roughly one third of those have been convicted. ${ }^{8}$ Enron's auditor, Arthur Andersen LLP, one of the largest accounting firms in the world, was charged with and convicted of one count of obstruction of justice in relation to its Enron activities. ${ }^{9} \quad$ Anderson subsequently

4. For an interesting list of the 100 most serious corporate criminal crimes of the 1990s (ranked by the size of the criminal fine imposed), see Russell Mokhiber, Top 100 Corporate Criminals of the Decade, at http://www.corporatepredators.org/top100.html (visited May 31, 2004). The offenses fell into fourteen categories of crime: Environmental (38), antitrust (20), fraud (13), campaign finance (7), food and drug (6), financial crimes (4), false statements (3), illegal exports (3), illegal boycott (1), worker death (1), bribery (1), obstruction of justice (1), public corruption (1), and tax evasion (1). Nine of the twenty five most serious cases involved antitrust violations; the fines in those nine cases totaled approximately $\$ 1.2$ billion. The largest single fine, $\$ 500$ million, was imposed upon F. Hoffmann-La Roche Ltd. in 1999 for leading a worldwide conspiracy to fix and raise prices and allocate market shares for vitamins. Id. at 15. Mokhiber, the editor of the Corporate Crime Reporter, draws his data from that publication.

5. Bill Wasik, Dismal Beat: The March of Personal-Finance Journalism, Harper's Magazine, March 1, 2003, at 81.

6. Our View; Corporate Cruelty, Press Enterprise (Riverside, CA), February 23, 2004, at A10.

7. Kathleen F. Brickey, Enron's Legacy, 8 Buff. Crim. L. Rev. 221, 222-23 (2004). Over 6,500 employees lost their jobs and pensions while Enron executives awarded themselves $\$ 55$ million in bonuses. Id.

8. Robert Manor \& Howard Witt, Lay Charged with Massive Conspiracy; ExEnron CEO Pleads Innocent, Chicago Tribune, July 9, 2004, at C1.

9. Kathleen F. Brickey, Andersen's Fall from Grace, 81 Wash. U. L.Q. 917, 919-21 (2003). Andersen's Enron team shredded Enron-related documents until the company had been "officially served" by the SEC. Under SEC rules, a felony 
closed its public auditing practice in August 2002, reducing its workforce from 28,000 U.S.-based partners and employees to fewer than $3,000 .^{10}$

Many other major American corporations also misrepresented their finances, inflating earnings and assets, and concealing and mischaracterizing expenses. These included other energy companies, ${ }^{11}$ including Dynergy. The disclosure of Dynergy's use of fictive "round trip" energy trades to create an appearance of active trading resulted in losses estimated at $\$ 100$ million. $^{12}$ Technology and communications companies, ${ }^{13}$ including Adelphia Communications, ${ }^{14}$ WorldCom,${ }^{15}$ and Global

conviction disqualifies a company from auditing public companies unless the firm receives a waiver.

10. Id. at 917 n.1. The principle function of its remaining operation is winding up its business affairs.

11. Royal Dutch/Shell Group, the world's third largest oil company, reduced its estimates of its proven reserves of oil and natural gas by 20 percent, or 3.9 billion barrels, nearly two years after internal documents suggest that top executives may have known about the overstatement. Stephen Labaton \& Jeff Gerth, At Shell, New Accounting and Rosier Oil Outlook, N.Y. Times, March 12, 2004, at A1. In May 2004, El Paso Corporation announced that it would reduce its estimates of proven oil and natural gas reserves by 41 percent, or 1.8 trillion cubic feet, because several employees had deliberately overstated its reserves. Heather Timmons, El Paso Says Reserves May Have Been Falsified, N.Y. Times, May 4, 2004, at C14. Reliant Energy and four corporate officials were indicted for illegal activities during the California energy crisis in 2000, when the corporation allegedly executed illegal "round trip" trades in which the same electricity would be bought and sold at the same price, creating the illusion of trading activity to artificially increase the price of electricity. Former Reliant Electricity Trader Agrees to $\$ 25,000$ Fine, Los Angeles Times, May 11, 2004, at C2.

12. Simon Romero, Stiff Sentence Is Possibility for a Name Not so Known, N.Y. Times, March 24, 2004, at C1. Prosecutors reached this estimate by measuring the decline in Dynergy's stock-from $\$ 56.99$ in April 2001 to $\$ 0.86$ in August 2002.

13. In April 2004, Computer Associates, the fourth largest independent software company with 16,000 employees and more than $\$ 3$ billion in sales, acknowledged that it had backdated $\$ 1.8$ billion in contracts in the fiscal year ended March 2000, which amounted to nearly 30 percent of its total sales that year. Although the investigation is ongoing, four former executives have already pleaded guilty to securities fraud or obstruction of justice. Alex Berenson, Computer Associates Restates Timing of \$2.2 Billion in Sales, N.Y. Times, April 27, 2004, at C1.

14. In March 2002, Adelphia, the sixth largest cable operation in the United States, disclosed that company assets had been used as collateral for $\$ 2.3$ billion in secret loans to company executives who had artificially inflated earnings, 
Crossing $^{16}$ also suffered massive losses when their fraudulent accounting practices were revealed. In the health care industry, HealthSouth, the nation's largest operator of rehabilitation hospitals and surgery centers, engaged in an accounting fraud that inflated earnings and assets by as much as $\$ 4.6$ billion in order to meet Wall Street forecasts. ${ }^{17}$

Major European corporations also employed similar deceptive practices. Parmalat (a dairy-food giant which was the eighth largest industrial group in Italy and represented $.8 \%$ of the country's $\mathrm{GDP}^{18}$ ) collapsed in late 2003 after the revelation that it had falsified its earning reports for thirteen years, while it was losing billions of dollars, and claimed assets in a bank account that did not exist. ${ }^{19}$ Furthermore, nearly 4 billion Euros in market value was lost after the disclosure that Royal Ahold, ${ }^{20}$ a

hidden billions of dollars of debt, and improperly inflated subscriber numbers to artificially improve its financial standing. The founder of Adelphia and its chief financial officer have been convicted of conspiracy, bank fraud, and securities fraud. Barry Meier, 2 Guilty in Fraud at a Cable Giant, New York Times, July 9, 2004, at A1. To date, no criminal charges have been filed against the company. Carrie Johnson, Trial Against Adelphia Executives to Open; Father, 2 Sons Face Criminal Charges in Wide-Ranging Fraud Investigation, The Washington Post, February 23, 2004, at A05.

15. In 2002, WorldCom announced a multi-billion dollar second-quarter charge to write down some acquired operations and subsequently revealed fraudulent accounting practices that had improperly classified $\$ 3.8$ billion in ordinary expenses as capital expenditures. In March 2004, WorldCom reduced its combined pretax profits for 2000 and 2001 by $\$ 74.4$ billion. Although charges have been filed against company executives, to date, no criminal charges have been filed against the company. WorldCom Restates Profits by $\$ 74.4$ Billion for 2 Years, N.Y. Times, March 13, 2004, at C14.

16. In 2002, Global Crossing collapsed under $\$ 12.4$ billion in debt. The company allegedly counted the telecom capacity it sold to other telecommunications firms as revenue but failed to list as an ordinary expense the cost of buying capacity from others. No charges were filed against the company or its executives. Singapore Group Takes Global Crossing out of Bankruptcy, Channel NewsAsia, December 10, 2003.

17. Brickey, supra note 7, at 222-23. By May 2003, fourteen executives were investigated and the CEO was indicted in November 2003. Id.

18. Sophie Arie, Parmalat Dream Goes Sour, The Observer, January 4, 2004, at 3 .

19. Gail Edmondson \& Laura Cohn, How Parmalat Went Sour, Business Week, January 12, 2004, at 46.

20. Gregory Crouch \& Sherri Day, Another Ahold Executive Resigns in Wake 
Dutch company that had been the world's third largest food retailer, ${ }^{21}$ had overstated its earnings by more than a billion dollars. ${ }^{22}$

Other corporate wrongdoing involved breaches of environmental or health and safety laws. Three major cruise lines-Carnival, Norwegian, and Royal Caribbeanpleaded guilty to charges involving the dumping of waste oil, dry cleaning chemicals, and other toxic substances, and falsifying records to conceal this conduct. ${ }^{23}$ Smaller domestic companies violated the Clean Water Act by discharging wastewater into sewers, surface waters, and wetlands. ${ }^{24}$ Olympic Pipe Line Co. was convicted of violating the 1979 Pipeline Safety Act as a result of a pipeline rupture that killed three people in a park in Washington. ${ }^{25}$ Virtually all of the major pharmaceutical companies are being investigated or have settled or plead guilty to charges of serious misconduct. Pfizer, the world's largest pharmaceutical company, plead guilty and agreed to pay $\$ 430$ million to resolve criminal and civil charges that it paid doctors to prescribe an epilepsy drug to patients with ailments that the drug was not federally approved to treat, ${ }^{26}$ despite a study showing the drug was

of Scandal, N.Y. Times, May 14, 2003, at C5.

21. Dutch Grocer Tries for New Start with Write-Down, N.Y. Times, October 3,2003 , at W1.

22. Gregory Couch, At Ahold, Past Errors Shadow the Future, N.Y. Times, November 25, 2003, at W1.

23. Marilyn Adams, Cruise Ship Dumping Poisons Seas, Frustrates U.S. Enforcers, USA Today, November 8, 2002, at 1A.

24. PQ corporation improperly discharged wastewater into public sewers and surface waters and was ordered to pay a total of $\$ 557,000$ in fines and restitution to the areas affected and will also pay $\$ 50,000$ to fund community service projects. Also, Keystone Insulator-Cleaner, Inc. and its owner were indicted on one charge of conspiring to violate the Clean Water Act and two charges of violating the Clean Water Act by dumping wastes into wetlands located on McNally's property. Environmental Protection Agency Enforcement Wrap-Up, U.S. Newswire, May 25, 2004.

25. Carolyn Nielsen, Issues Remain in Pipeline Case, The Bellingham Herald (Bellingham, WA), December 22, 2002, at 5B.

26. Christopher Bowe, Pfizer to Pay $\$ 430$ Million for Drug Fraud, Finacial Times (London), May 14, 2004, at 20. This amount is the second largest criminal fine ever levied for healthcare fraud prosecution. Of the total, $\$ 240$ million was assessed as a criminal fine and $\$ 190$ million was assessed as a civil fine. Also, the 
no more effective than a placebo in treating other disorders. ${ }^{27} \quad$ British pharmaceutical manufacturer AstraZeneca paid a total of $\$ 355$ million, including a criminal fine of $\$ 64$ million, to settle accusations of fraud against Medicare concerning a prostate cancer drug. ${ }^{28}$ Bayer has paid $\$ 271$ million and GlaxoSmithKline has paid more than $\$ 86$ million to settle allegations that they relabeled drugs to mislead Medicaid officials. ${ }^{29}$ Abbott Laboratories paid more than $\$ 622$ million to settle an investigation into its marketing practices. ${ }^{30}$ Finally, Schering-Plough Corporation is under investigation of its marketing practices as well as allegations that employees destroyed documents related to the case. ${ }^{31}$

At least one U.S. corporation has an extensive record of violations causing injuries and deaths. McWane, Inc., a privately held company with approximately 5,000 employees, is one of the world's largest manufacturers of cast-iron sewer and water pipe. ${ }^{32}$ Since 1995 , at least 4,600 injuries have been recorded in McWane foundries, ${ }^{33}$

fines were for activities conducted by Warner-Lambert before that company was purchased by Pfizer in 2000.

27. Gardiner Harris, Pfizer to Pay $\$ 430$ Million over Promoting Drug to Doctors, N.Y. Times, May 14, 2004, at C1. Nearly 90 percent of the drug's sales continue to be for ailments for which the drug is not an approved treatment. The company also illegally promoted the drug as treatment for Lou Gehrig's disease, attention deficit disorder, restless leg syndrome, and drug and alcohol withdrawal seizures.

28. Melody Petersen, AstraZeneca Pleads Guilty in Cancer Medicine Scheme, N.Y. Times, Saturday, June 21, 2003, at C1.

29. Two More States in AWP Fray; One Seeks Damages Related to Old Federal Cases, Pharmaceutical Corporate Compliance Report, March 16, 2004, at Vol. 2, No. 6 .

30. Gardiner Harris, Abbott to Pay $\$ 622$ Million to End Inquiry into Marketing, N.Y. Times, June 27, 2003, at C1.

31. Melody Petersen, Indictment Seen By Drug Maker Over Marketing, N.Y. Times Online, May 31, 2003, at A1 (late edition). If any company is convicted of a felony involving health care fraud, the government could seek to bar its prescription drugs from the federal Medicare and Medicaid programs.

32. David Barstow, \& Lowell Bergman, Criminal Inquiry Under Way at Large Pipe Manufacturer, N.Y. Times, May 15, 2003, at A1.

33. David Barstow \& Lowell Bergman, At a Texas Foundry, an Indifference to Life, N.Y. Times, January 8, 2003, at A1. At one plant in Texas, a report issued by the federal Occupational Safety and Health Administration stated, "Workers are covered with black residue from the foundry sand. Many work areas are 
including ten deaths. ${ }^{34}$ McWane has been cited for hundreds of safety and environmental violations stemming from management's cost cutting efforts. ${ }^{35}$ It has been convicted in the state courts of New York and Texas, has deliberately ignored and willfully violated OSHA safety rules, and now faces additional charges of health and safety violations. $^{36} \quad$ As of May 2003, McWane had paid approximately $\$ 10$ million in fines. ${ }^{37}$

The prevalence of serious corporate malfeasance highlights the importance of legal regimes that respond to-and may prevent or deter-corporate wrongdoing. Western Europeans nations use a variety of administrative, civil, and criminal laws to address corporate misconduct. In this article, we focus on corporate criminal liability without meaning to underplay the importance of other mechanisms. Section I describes the academic criticisms and defenses of corporate criminal liability in the American legal literature. Section II reviews the development of corporate criminal liability in Western Europe. Section III considers the nature of the developments noted in Western Europe, and explores their implications for the United States. Although there has been much discussion regarding the Sarbanes-Oxley Act's impact in the United States and even in Europe, it is not the subject of our review, because expanded criminal liability under Sarbanes-Oxley is targeted primarily at corporate officers and directors rather than at the corporate entity itself. ${ }^{38}$ In

dark, due to poor lighting and clouds of sand. Despite all the ignition and fuel sources, exit paths are not obvious."

34. Robin Stein, Worker is Crushed to Death at Troubled Foundry Upstate, N.Y. Times, February 21, 2004, B5.

35. Barstow \& Bergman, supra note 33, at A1.

36. David Barstow \& Lowell Bergman, Deaths on the Job, Slaps on the Wrist, N.Y. Times, January 10, 2003, at A1. The company has also been indicted in New Jersey and Alabama for environmental crimes. Andrew Dunn, McWane Accused of Pollution, Deseret Morning News (Salt Lake City), May 27, 2004, at E3.

37. Barstow \& Bergman, supra, note 33, at A1.

38. See 18 U.S.C. $§ \S 1348-1350$; U.S. Sentencing Commission Supplement to the 2002 Guidelines Manual §2B1.1 (2003). It should be noted, however, that in response to Sarbanes-Oxley, which directed the Sentencing Commission to reexamine the guidelines governing corporate offenders, the Sentencing 
this article, we focus on justifications for imposing criminal liability on the corporate entity as opposed to its officers and directors. We do not address here the question, posed by some law and economics scholars, of whether economic offenses should be criminalized in the first place.

\section{CONTEMPORARY ATTITUDES TOWARD CORPORATE CRIMINAL LIABILITY IN THE UNITED STATES}

Corporate criminal liability has become controversial in the United States. Several different critiques have been offered. Some critics begin from a retributive view of the function of criminal law, others from a utilitarian perspective. Most of the utilitarian analysis focuses directly on the efficiency of using criminal sanctions on the corporate entity, though a closely related strand connects these arguments to public choice theory. Although the critics do not agree on first principles, they concur in the conclusion that corporations should be sanctioned (exclusively or in all but exceptional cases) in civil rather than criminal proceedings. Other scholars defend corporate criminal liability, some on the ground of the expressive function or social meaning that attaches to criminal law, and others on more pragmatic grounds such as the resources available for the enforcement of criminal law.

\section{A. The Retributive Critique of Corporate Criminal Liability}

One line of criticism asserts that the traditional forms and functions of criminal law should not be applied to juridical persons, because they cannot in any meaningful sense be said to have mens rea or to be "guilty" of a

Commission amended the guidelines, effective November 1, 2004, to impose stricter criteria for corporate compliance programs. See Amendments to the Sentencing Guidelines, supra note 2. These amendments are relevant to our comparative review of sanctions imposed on corporate offenders. See infra note 300 and accompanying text. 
criminal offense. ${ }^{39}$ Imposing criminal liability on a corporate entity requires resort to the principles of respondeat superior, rather than individual responsibility, which is the hallmark of the criminal law. Accordingly, using the criminal justice system to convict or punish a corporation is undesirable because it obscures the moral content of criminal liability. ${ }^{40}$ This critique is consistent with a retributivist or desert-based view of the function of criminal law, which imposes punishment on the basis of the offender's moral blameworthiness, in order to respond to the wrong manifest in the criminal conduct. ${ }^{41}$

\section{B. The Law and Economics Efficiency Critique}

Another line of criticism of corporate criminal liability is founded on a law and economics perspective and a utilitarian view of the function of criminal law. Assuming for our purposes the efficacy of using the criminal law in some instances to regulate economic conduct-an

39. Daniel R. Fischel \& Alan O. Sykes, Corporate Crime, 25 J. Legal Stud. 319, 320 (1996) ("Corporations are legal fictions, and legal fictions cannot commit criminal acts. Nor can they possess mens rea, a guilty state of mind."); Paul H. Robinson, The Criminal-Civil Distinction and the Utility of Desert, 76 B.U. L. Rev. 201, 211 n.40 (1996). See also V.S. Khanna, Is the Notion of Corporate Fault a Faulty Notion?: The Case of Corporate Mens Rea, 79 B.U. L. Rev. 355, 356 (1999) (advocating corporate criminal liability based upon negligence or strict liability because of the incoherence of the concept of corporate mens rea).

40. John Baker, Corporations Aren't Criminals, Wall St. Journal, April 22, 2002 , at A3 (corporate criminal liability "ignores the moral basis on which substantive criminal law rests - the requirement that a defendant be personally responsible for his actions"); Paul H. Robinson, The Practice of Restorative Justice: The Virtues of Restorative Process, the Vices of "Restorative Justice," 2003 Utah L. Rev. 375, 384-85 (extending criminal liability to corporations "risks obscuring the moral content of criminal liability"). David Skeel and William Stuntz have cautioned that if criminal law is expanded to cover more technical violations, trials - which by their nature tend to focus on behavior on the outer edge of criminal liability, rather than the core-will increasingly deal with technicalities and trivialize the criminal law. David Skeel \& William Stuntz, Another Attempt to Legislate Corporate Honesty, N.Y. Times, July 10, 2002, at A21.

41. Cf. Robinson, supra note 39 , at 210-11 (using a retributive-desert model to analyze the expansion of criminal sanctions to cover behavior traditionally the subject of civil law). 
assumption obviously not accepted by all law and economics scholars - the law and economics critique focuses on whether criminal sanctions are the most efficient response to corporate misconduct. Law and economics scholars believe that civil entity liability is a more efficient response, or that individual liability (either civil or criminal) is preferable to entity liability.

In general, law and economics scholars have agreed that criminal sanctions are not an efficient response to corporate misconduct, though they have reached that conclusion based upon different-and in some cases inconsistent-reasoning. One line of critique sees criminal sanctions as too powerful. Because criminal sanctions are so potent, they tend to overdeter, inducing enterprises to spend more resources on monitoring and compliance than is socially useful. ${ }^{42}$ According to this account, civil sanctions can be more precisely calibrated, and hence more efficient at matching the costs of compliance with the expected social benefit. ${ }^{43}$ (Additionally, if sanctions are large enough to be meaningful, they will tend to have a spillover effect, injuring relatively blameless shareholders and employees. ${ }^{44}$ )

Law and economics theorists have also focused on two distinctive attributes of criminal liability: procedural requirements and the reputational effects of conviction. Law and economic analysis treats the heightened procedural requirements in criminal proceedings (such as proof beyond a reasonable doubt, trial by jury, and double jeopardy) as increased transaction costs. Since a corporation cannot be imprisoned, both civil and criminal proceedings generally

42. Fischel \& Sykes, supra note 39, at 321. See also Bruce H. Kobayashi, Antitrust, Agency, and Amnesty: An Economic Analysis of the Criminal Enforcement of the Antitrust Laws Against Corporations, 69 Geo. Wash. L. Rev. 715,744 (2001) (concluding that increased enforcement of antitrust laws under the Clinton Administration probably caused corporations to take too many precautions ex ante and thus made the system less efficient).

43. Fischel \& Sykes, supra note 39 , at 321.

44. John C. Coffee, Jr., "No Soul to Damn: No Body to Kick": An Unscandalized Inquiry into the Problem of Corporate Punishment, 79 Mich. L. Rev. 386, 386-87 \& n.4 (1981). 
result in monetary penalties, and law and economic scholars question whether the increased transaction costs of the criminal process can be justified. ${ }^{45}$ Criminal conviction also imposes a stigma or reputational penalty. ${ }^{46}$ Law and economics scholars have expressed a variety of concerns regarding the reputational damage that criminal charges and criminal convictions can impose upon corporations. ${ }^{47}$ On the one hand, there is concern that a corporation may suffer unjustified reputational harm if it is convicted of a relatively minor criminal charge. ${ }^{48}$ On the other hand, in the case of the most serious offenses, reputational harm may be warranted, but in such cases the nature of the facts may speak for themselves, creating a public outcry, to which criminal charges add little or nothing. ${ }^{49}$ By this reasoning, reputational harm is either unnecessary or excessive. Indeed, reputational sanctions may have a perverse quality. They are most effective when applied to firms with good reputations, and they are ineffective if a firm has not yet created, or has already lost, its positive reputation. ${ }^{50}$ Thus firms whose general conduct has been exemplary will suffer the greatest reputational damage from criminal charges, and bad corporate actors will be immune from reputational

45. V.S. Khanna, Corporate Criminal Liability: What Purpose Does It Serve?, 109 Harv. L. Rev. 1477, 1512-20 (1996) (noting, however, that where sanctions are high and legal standards uncertain, the greater procedural protections afforded by the criminal process may be warranted).

46. Although the scholarship generally treats the existence of this reputational effect as a given, there has been surprisingly little effort to establish its existence empirically. One study found no effect on share prices of news reports of civil charges and settlements of fraud charges compared with reports of malum prohibitum criminal charges. See Michael K. Block, Optimal Penalties, Criminal Law and the Control of Corporate Behavior, 71 B.U. L. Rev. 395, 413-15 (1991).

47. The literature also contains an interesting discussion of the impact of the "rub off" effect of reputational penalties on corporate officers, managers, and other employees. V.S. Khanna has defined a set of criteria that define the circumstances under which such rub off penalties are warranted and effective. Khanna, supra note 45 , at 1509-12. See also Fischel \& Sykes, supra note 39, at 342 (discussing rub off penalties in the context of Michael Milken and Drexel Burnham Lambert).

48. Fischel \& Sykes, supra note 39 , at 332 .

49. Khanna, supra note 45 , at 1509 .

50. Id. at 1500 . 
sanctions. Moreover, the reputational loss to a firm that has been convicted of criminal conduct, unlike a civil judgment awarding monetary damages, does not provide a reciprocal gain to any injured party. ${ }^{51}$ It is thus far less efficient than a sanction that provides such a benefit. ${ }^{52}$ It should be noted, however, that from an efficiency perspective, the reputational effects of criminal charges do provide two related benefits to the prosecution. Reputational effects ensue immediately when charges are filed, and accordingly they impose pressure on firms (as well as individuals) to engage in rapid plea discussions to limit the reputational damage..$^{53}$ Of course these benefits to the prosecution may be deemed undesirable from a broader social vantage point, since they impose a penalty with few procedural protections, and may create undue pressure on a corporation to plead guilty even to unfounded charges in order to reduce the impact of the negative publicity that occurs throughout criminal proceedings.

\section{The Public Choice Critique}

In contrast to the traditional law and economics analysis-which assumes criminal sanctions are unduly severe, inflicting unjustified, excessive, and sometimes perverse costs on corporations and their officers, shareholders, and employees-a more recent critique has suggested that imposing criminal sanctions on a corporation is actually the least costly penalty from the firm's point of view, raising the concern that criminal liability may underdeter corporate misconduct. ${ }^{54}$ This new argument is

51. Id. at 1503,1505 .

52. Law and economics scholars have made a similar argument in favor of using criminal fines rather than imprisonment whenever possible, because fines return resources to the public (and allow the defendant to remain self supporting and productive), but imprisonment imposes substantial costs. See, e.g., Richard A. Posner, Optimal Sentences for White-Collar Criminals, 17 Am. Crim. L. Rev. 409, 409-11 (1980); Joel Waldfogel, Are Fines and Prison Terms Used Efficiently? Evidence on Federal Fraud Offenders, 38 J.L. \& Econ. 107, 107 (1995).

53. Khanna, supra note 45 , at $1505-08$.

54. V.S. Khanna, Corporate Crime Legislation: A Political Economy 
based on public choice theory and its recognition of the important role interest groups play in the legislative process ${ }^{55}$ and on the observation that in several instances corporate interests have opposed the expansion of corporate criminal liability less vigorously than enhanced civil liability for corporate entities or criminal liability for corporate officers and agents. ${ }^{56}$ Given the political power wielded by corporate interests, their relatively muted opposition to corporate criminal liability suggests that they view criminal penalties as less problematic than other sanctions.

In addition, the public choice analysis incorporates many of the arguments described above regarding the relative inefficiency of criminal sanctions, but instead of concluding that criminal sanctions overdeter corporate economic activity, it concludes that they may underdeter corporate misconduct. As compared with enforcement through private civil actions, criminal enforcement has typically been thin, ${ }^{57}$ and criminal fines often less than civil penalties. ${ }^{58}$ Moreover, since only the government can enforce criminal laws, corporate interests can later lobby below the political radar to limit enforcement by limiting the enforcement budget. ${ }^{59}$ Finally, in criminal proceedings the government must meet additional procedural and substantive hurdles. For these and other reasons, corporate interests may see the creation or expansion of corporate criminal liability as the lesser evil at times when

Analysis, Discussion Paper No. 03-012, University of Michigan John N. Ohlin Center for Law and Economics (2003), available at http://www.law.umich.edu/CentersAndPrograms/olin/papers.htm\#2003 at 3, 46. For a general application of public choice theory to criminal legislation, see William J. Stuntz, The Pathological Politics of Criminal Law, 100 Mich. L. Rev. 505 (2001).

55. For a general discussion of interest groups and public choice theory, see Daniel A. Farber \& Philip P. Frickey, Law and Public Choice: A Critical Introduction 12-37 (1991).

56. Khanna, supra note 54, at 21-23 (discussing the Private Securities Litigation Reform Act of 1995, the Foreign Corrupt Practices Act, and SarbanesOxley).

57. Id. at $12-13$.

58. Id. at 13-14.

59. Id. at 8 n. $40,17-18$. 
the pubic demands legislative action to respond to corporate wrongdoing. ${ }^{60}$ According to this analysis, corporate interests will more strenuously oppose more effective legislation creating civil liability for corporations, or criminal liability for corporate officers, directors, and management, and corporate criminal liability may be enacted as a substitute for more effective laws. Thus the enactment of corporate criminal liability may actually have the perverse effect of underdeterring corporate misconduct.

\section{Defenses of Corporate Criminal Liability}

Despite the range of criticisms, corporate criminal liability also has its American defenders. Since heightened procedural protections plainly do impose some additional procedural costs, many advocates of employing criminal liability base their arguments on the distinctive functions of criminal law. Some scholarly defenses of criminal liability for corporations focus on the expressive function of criminal law, and reason that criminal sanctions are necessary to respond to corporate wrongdoing that denigrates the value of the persons and interests injured by corporate wrongdoing. ${ }^{61} \quad$ Similarly, a social meaning analysis emphasizes that criminal law expresses society's condemnation of prohibited activities. ${ }^{62}$ Replacing corporate criminal liability with civil liability conveys the message that the right to engage in prohibited activities can be purchased; only corporate criminal liability can provide both the incentives necessary to prevent crime and a vehicle for

60. See id. at 19 (arguing that corporate interests would prefer criminal liability, with its heightened procedures, over civil liability); see id. at 21-22 (noting successful passage of Sarbanes-Oxley after major corporate accounting scandals but unsuccessful attempt post-Enron to repeal recent limitations on private securities actions).

61. Lawrence Friedman, In Defense of Corporate Criminal Liability, 23 Harv. J.L. \& Pub. Pol'y 833, 858 (2000). But see Vikramaditya S. Khanna, Should the Behavior of Top Management Matter?, 91 Geo. L.J. 1215, 1218 (2003) (suggesting that expressive considerations can be furthered by other, less socially costly, forms of liability).

62. Dan M. Kahan, Social Meaning and the Economic Analysis of Crime, $27 \mathrm{~J}$. Legal Stud. 609, 617 (1998). 
the message that certain activities are prohibited and variances cannot be purchased..$^{63}$

Using the criminal justice system to respond to corporate misconduct also has pragmatic advantages. There is no comprehensive civil counterpart to the extensive network of federal and state prosecutors and investigators who make up the "great infrastructure of criminal law enforcers." ${ }^{4}$ If corporations cannot be held liable for criminal conduct, this infrastructure will be unavailable to investigate corporate wrongdoing, and there may not be adequate resources for administrative and civil enforcement. ${ }^{65}$ There are also some procedural advantages. Although criminal procedure provides defendants with heightened procedural rights, it also provides a significant advantage to the government, particularly the power of investigative grand juries. ${ }^{66}$ Additionally, the greater speed with which criminal charges are generally resolved ${ }^{67}$ means that they can bring speedier restitution to victims. ${ }^{68}$ Corporate criminal liability can also provide a basis for desirable sanctions other than monetary fines, such as equity fines and corporate probation. ${ }^{69}$

To provide a new lens through which to illuminate the debate about the legitimacy of corporate criminal liability in American law, we turn now to the recent developments in Europe.

63. Id. at 619 .

64. Coffee, supra note 44 , at 447 .

65. Id. at 447-48.

66. For a general introduction to the grand jury, see Sara Sun Beale et al., Grand Jury Law and Practice (2d ed. 1997).

67. Criminal cases receive priority because of the constitutional and statutory guarantees of the right to a speedy trial. See Sara Sun Beale, Federalizing Crime: Assessing the Impact on the Federal Courts, 543 Annals Am. Acad. Pol. \& Soc. Sci. 39, 46-48, 50 (1996) (noting that increases in the criminal caseload required federal courts to give priority to criminal trials to avoid speedy trial dismissals; this forced more civil cases off the trial docket and into alternative dispute resolution).

68. Coffee, supra note 44 , at 447 .

69. Id. at $448-59$. 


\section{The DeVelopments IN WeStern EuROPE}

While the preceding philosophical and policy debate has been occurring in the United States, a debate of a different kind has been occurring in Western European countries. Other than Great Britain (which, by the 1950s, had adopted a more limited form of the respondeat superior theory of American corporate criminal liability ${ }^{70}$ ), Western European legal systems fundamentally resisted the imposition of criminal liability on legal entities throughout most of the last century. ${ }^{71}$ This opposition was expressed in the principle societas delinquere non potest, that is, a legal entity cannot be blameworthy. ${ }^{72}$

In this section we describe a fundamental shift in the European approach, and the widespread (though not uniform) adoption of corporate criminal liability. In part A of this section, we will briefly describe some of the events that drew attention to the issue of corporate criminal liability in Western Europe. Then, in part B, we will highlight some of the recent legislative developments imposing corporate criminal liability in the Netherlands, Denmark, Finland, and Switzerland. In parts C and D, we will discuss developments and continued debate in France and Germany, respectively, since they are two of the most

70. John C. Coffee, Corporate Criminal Liability: An Introduction and Comparative Survey, in Criminal Responsibility of Legal and Collective Entities, 9, 11-12, 14 (Albin Eser et al. eds., 1999); L.H. Leigh, The Criminal Liability of Corporations and Other Groups: A Comparative View, 80 Mich. L. Rev. 1508, 1510-11 (1981).

71. The exception was Denmark, which has recognized corporate criminal liability for certain offenses since 1926. See Coffee, supra note 70, at 24. In 1996, a statutory framework for corporate criminal liability was included in the Danish criminal code. Gorm Toftegaard Nielsen, Criminal Liability of Collective Entities-the Danish Model, in Criminal Responsibility of Legal and Collective Entities, supra note 70, at 189, 190.

72. See Günter Heine, New Developments in Corporate Criminal Law Liability in Europe: Can Europeans Learn from the American Experience-Or Vice Versa?, 1998 St. Louis-Warsaw Transatlantic L.J. 173, 174 (1998); Leigh, supra note 70, at 1509; Mireille Delmas-Marty, Les Conditions de fond de mise en jeu de la responsibilité pénale, 111 Revue des Sociétés (Dalloz, April-June 1993) at 301 . 
significant civil law systems in Western Europe. ${ }^{73}$ In addition, we will focus in more depth on the new French law imposing corporate criminal liability for another reason: as best we can determine, France's new law is more comprehensive than other statutory schemes, particularly in its provision of extensive non-monetary sanctions. Although we have not canvassed all other developments in Western European countries, we note that Belgium, Norway, and Portugal have also introduced varying degrees of corporate criminal liability. ${ }^{74}$ Spain and Italy, however, continue to resist imposing full corporate criminal liability, but like Germany, they have imposed quasicriminal administrative liability. ${ }^{75}$

73. "Traditionally, France has been considered 'the motherland of modern codification, and the Napoleonic Code Pénal is the most widely followed penal code in the world." Leonard Orland \& Charles Cachera, Corporate Crime and Punishment in France: Criminal Responsibility of Legal Entities (Personnes Morales) Under the New French Criminal Code (Nouveau Code Pénal), 11 Conn. J. Int'l L. 111, 113 (1995) (quoting Gerhard O.W. Mueller, Foreward to 1 The French Penal Code xiii (Gerhard O.W. Mueller ed., Jean F. Moreau \& Gerhard O.W. Mueller trans., 1960)). German criminal law theory has "widespread influence in the civil law world," affecting many European countries, as well as Latin American and Asian nations. Markus Dirk Dubber, The Promise of German Criminal Law at 1 (unpublished manuscript on file with author, Feb. 22, 2004).

74. Portugal imposed vicarious agency liability in the areas of economic and environmental crimes. Coffee, supra note 70 , at 24 . Norway established corporate criminal liability for certain offenses, but there is very little English commentary on Norwegian developments. Heine, supra note 72, at 175; Manfred Möhrenschlager, National and International Developments, in Criminal Responsibility of Legal and Collective Entities, supra note 70, at 89, 91. Finally, on May 4, 1999, the Belgium parliament surprised some observers by adopting criminal liability for corporations. Under the new law, according to one observer, "the legal entity is considered criminally liable for crimes which are connected to the purpose of the legal entity or which have been committed in its interest or for its account." Michael G. Faure, Criminal Responsibilities of Legal and Collective Entities: Developments in Belgium, in Criminal Responsibility of Legal and Collective Entities, supra note 70, at 105, 111. In contrast to the French law and other proposals discussed later in this section that preserve individual criminal liability, the Belgian law, according to Faure, "excludes the liability of the individual person, unless the latter knowingly committed a fault," when the corporation is liable. Id.

75. In Italy and Spain, legislatures increasingly imposed quasi-criminal administrative sanctions on corporations to "confront the growing power of economic enterprises." See Heine, supra note 72, at 174; C.E. Paliero, Criminal 
Finally, in part E, we will highlight some proposals of two transnational European organizations, the Council of Europe and the European Union. Although member states have not embraced wholeheartedly the proposals for criminalizing certain corporate conduct in social and economic fields, those proposals are still significant. As reflections of the views of representatives of member state governments, these proposals may signal the direction of future policy in the member states and influence legislative initiatives in those states.

\section{A. Western European Scholars Confront the Need for Corporate Criminal Liability}

By the late 1970s, legal scholars and commentators in Western Europe were increasingly challenging the viability of the principle of societas delinquere non potest, believing that the subject of the criminal responsibility of corporations could not be avoided. ${ }^{76}$ This was driven,

Liability of Corporations-Italy, in Criminal Liability of Corporations, XIVth International Congress of Comparative Law 251, 265 (Hans de Doelder \& Klaus Tiedemann eds., 1996 Kluwer Law International) (noting that since 1981, "the principles behind and the structure of administrative torts have been closely connected to the criminal model which is today so well known in Europe, the modern prototype of which is to be found in the German Ordnungswidrigkeiten"). In Italy, movement toward corporate criminal liability faces a fundamental obstacle, namely, the constitutional prescription that "criminal liability is personal." Id. at 253 (citing art. 27, II 1, of the Italian Constitution). A strict reading of this clause to require individual culpability was re-affirmed in 1988 by Italy's Constitutional Court. Id. at 255, 258-59. Nevertheless, as Paliero notes, this decision has not deterred scholars from continuing to explore possible models for corporate liability, especially since there is a wide consensus that the "more invasive activities of companies and corporations" cannot be controlled without punitive sanctions. Id. at 261, 259-71. Paliero further argues that corporations have "interests which are distinct from those of physical persons," and therefore are capable of committing criminal offenses. Id. at 257. Another Italian scholar has also argued for the development of corporate criminal liability: "The classical construction of criminal offences based on a human scale is increasingly unable to deal with the emergence of new, collective or complex entities, the latter of which prevail ever more in the most characteristic sectors of modern crime, for example, organized and economic crime." Vincenzo Militello, The Basis for Criminal Responsibility of Collective Entities in Italy, in Criminal Responsibility of Legal and Collective Entities, supra note 70, at 181, 181.

76. Klaus Tiedemann, Introductory Note, in Criminal Liability of 
primarily, by the increasing economic influence of corporations in Western Europe ${ }^{77}$ and the unique threats posed to society from unregulated corporate misconduct in such areas as consumer markets and the environment. ${ }^{78}$ Corporate misconduct was viewed as a new form of "delinquency" worthy of criminal sanction. ${ }^{79}$ As a consequence, some commentators were willing to conceive that the corporation itself had its own personality and was capable of being imprinted with criminal blameworthiness, ${ }^{80}$ even if the concept of inflicting punishment on a corporation posed its own conundrum. ${ }^{81}$

In France, the largest of the civil law Western European countries to have adopted comprehensive

Corporations, XIVth International Congress of Comparative Law, supra note 75, at 1,1 (noting academic conferences organized to address the "criminal liability of enterprises," including the 10th International Congress of Comparative Law in Brussels in 1978, International Centre of sociological, criminal and penitentiary research and studies in Messine in 1979, and the meeting of German, Austrian and Swiss professors of criminal law in Basel in 1993).

77. Leigh, supra note 70, at 1508-09.

78. Klaus Tiedemann, Rapport général, in Criminal Liability of Corporations, in Criminal Liability of Corporations, XIVth International Congress of Comparative Law, supra note 75, at 11, 14. See Günter Heine, Criminal Liability of Enterprises and New Risks: International Developments, National Consequences, 2 Maastricht Journal of European and Comparative Law 107, 108 (1995) (noting that corporations in Western Europe do not face serious sanctions for environmental harm caused by their conduct).

79. Tiedemann, supra note 78 , at 14 .

80. Id. at 25 . Tiedemann notes that corporations were increasingly regarded as creating a climate which encouraged the commission of offenses on behalf of the corporation by its representatives. Id. at 14. Cf. Heine, supra note 78, at 107 ("The international trend is towards imposing criminal liability on the enterprise, increasingly independent of proof of misconduct by a particular individual.").

81. See Tiedemann, supra note 78, at 15-18 (discussing the effectiveness of monetary and non-monetary sanctions in both the civil and criminal context in Western Europe); Heine, supra note 78, at 110 (“. . . a continuing lessening of the parameters of criminal responsibility would lead to a liability which is no longer of great consequence to anyone.... Even exclusively deterrent considerations face special difficulties when it is a question of determining guilt and imposing criminal sanctions in connection with entrepreneurial activity."). Cf. Leigh, supra note 70, at 1526 ("Scholars who advocate reform in Europe wish to have the power not only to fine a corporation, but also to subject it to other measures, for example, closure of premises, disqualification from pursuing a professional activity, confiscation, and more original still, placing the corporation under judicial supervision. Dissolution has also been envisaged.") (footnotes omitted). 
corporate criminal liability to date, ${ }^{82}$ there was an increasing sense that economically powerful entities that existed due to the state's "patrimony" should also be responsible to society for their conduct. ${ }^{83}$ Discussion about the use of criminal and administrative sanctions to regulate corporate conduct continued among legislative reformers and legal commentators in France throughout the 1980s. ${ }^{84}$ During this period, the French confronted the consequences of unregulated corporate activities, including the growth in the power of multinational corporations and their ability to evade local regulatory requirements, ${ }^{85}$ notorious corporate fault, such as the case involving the sale of blood tainted with the HIV virus by national agencies responsible for the collection and distribution of

82. On July 22,1992, the French legislature passed the Nouveau Code Pénal, which constituted a comprehensive revision of the French criminal code. One of the innovations in the new penal code were provisions imposing corporate criminal liability, which became effective on March 1, 1994. Bernard Bouloc, La Criminalisation du Comportement Collectif-France, in Criminal Liability of Corporations, XIVth International Congress of Comparative Law, supra note 75, at $235,237$.

83. Id. at 236-37.

84. Orland \& Cachera, supra note 73, at 121-22 (noting 1978 and 1986 attempts to pass legislation in France on corporate liability before passage in 1992 of the new penal code).

By the 1980s, French law imposed quasi-criminal liability on corporations for offenses concerning tax fraud, foreign exchange offenses, price-fixing, and, in narrow circumstances, worker safety. See Leigh, supra note 70 , at 1520 . This liability appears to be administrative in nature, although Leigh characterizes it as criminal. We are not aware of any French commentator who has suggested that formal corporate criminal liability existed before the adoption of the 1992 new French penal code. Moreover, Leigh's piece notes that while the French government imposed "criminal responsibility" on corporations operating as cartels or abusing dominant market positions by the early 1980s, French academics argued that the French government "limited itself to administrative sanctions," and was reluctant "to cross the Rubicon and impose full corporate criminal liability." Id. This would tend to confirm our understanding that other instances of what Leigh refers to as "criminal" liability imposed on corporations before 1992 were really administrative in nature. France adopted a comprehensive liability scheme in 1992, which will be discussed further below. See infra text accompanying notes 115-40.

85. See generally Mireille Delmas-Marty \& Klaus Tiedemann, La Criminalité, Le Droit Pénal et Les Multinationales, 1979 Juris-Classeur Periodique, la Semaine Juridique, (J.C.P.) II no. 53, at I 2935 (discussing role of criminal law in relation to conduct of multi-national corporations). 
blood in France, ${ }^{86}$ and unfair trade practices injuring consumers. ${ }^{87}$ Opponents of corporate criminal liability, however, in addition to their doctrinal resistance, argued that heavy administrative fines were sufficient to address corporate misconduct, and that imposing criminal liability would only harm a corporation's shareholders, employees, and creditors. ${ }^{88}$

\section{B. Breaking Free from Traditional Doctrinal Restraints}

The modern trend in Western Europe of imposing criminal responsibility on corporations began in 1970 and continues to the present time. In this section, we will briefly review developments in some European countries before focusing in more depth on developments in France and Germany.

\section{The Netherlands}

In 1976, the Netherlands became one of the first Western European countries to adopt legislation enacting comprehensive corporate criminal liability. The legislation made corporations liable for all offenses, expanding on criminal liability that had previously been limited to economic crimes. ${ }^{89}$ The 1976 legislation also dispensed with the requirement that liability be predicated on the actions of natural persons acting on the corporation's behalf, which was a requirement of the previous 1951 law. ${ }^{90}$ Liability may be predicated on deficient decision-making

86. Orland \& Cachera, supra note 73 , at n. 52 and accompanying text.

87. See Bouloc, supra note 82 , at 237.

88. Orland \& Cachera, supra note 73 , at 122.

89. Hans de Doelder, Criminal Liability of Corporations-Netherlands, in Criminal Liability of Corporations, XIVth International Congress of Comparative Law, supra note 75 , at 289, 291-92. This legislation is codified in paragraph 51 of the Dutch Penal Code. Id. Doelder notes that the difference between the use of criminal and administrative procedures is that in the case of the former, "the government aims at prevention, retaliation and intentional infliction of grief; the adminstrative intervention aims at reparation with less moral intention." Id. at 294.

90. Doelder, supra note 89 , at $291-92$. 
structures within the corporation or on the aggregate knowledge of multiple individuals. ${ }^{91}$ Dutch courts appear to have formulated negligence-style standards in assessing corporate liability. ${ }^{92}$ At the same time, it appears that respondeat superior liability has been preserved under Dutch law. ${ }^{93}$ Dutch prosecutors now have the ability to prosecute either or both the corporation and persons actually responsible for the offense. ${ }^{94}$

\section{Denmark}

In 1926, with the passage of the Butter Act, Denmark introduced corporate criminal liability for some offenses. ${ }^{95}$ By the end of the century, Denmark had greatly expanded the list of enterprise offenses. ${ }^{96}$ Recently, in 2002, the Danish criminal code was amended to provide that legal persons may be liable for all offenses within the general criminal code. ${ }^{97}$ However, offenses under other specialized laws, such as the Companies Act or the Act of Chartered Accountants, must specifically state whether they are applicable to legal entities. ${ }^{98}$

91. Coffee, supra note 70, at 21-22. It has been said that the Netherlands has established "functional liability (functioneel daderschap)" in the area of socioeconomic legislation, in which courts look to whether the corporation's management "had the power to decide whether those acts [the offense] took place or not, and the acts were parts of acts the occurrence of which according to the regular course of events was commonly accepted or commonly is accepted by the corporation.” J.A.W. Lensing, The Netherlands, in 3 International Encyclopedia of Laws, Criminal Law II 187 (1997 Kluwer Law International).

92. Coffee, supra note 70 , at 22 .

93. Id. at 21-22. Lensing states that respondeat superior liability does not exist under Dutch law; however, his conclusion appears to be based on a highly formalistic distinction in theory. Lensing, supra note 91, II 174. In fact, under the functional liability approach described by Lensing, respondeat superior liability may apply, at least where management was aware of and permitted the offense to occur.

94. Doelder, supra note 89 , at 305 . Doelder notes that in some cases, a prosecutor may wish to impose liability on a natural person rather than on the corporate entity. Id.

95. Nielsen, supra note 71 , at $189,190$.

96. Id.

97. Section 306 of the Danish Criminal Code (DJØF Publishing, 2d ed. 2003).

98. Lars Bo Langsted et al., Denmark, 2 International Encyclopedia of Laws, 
The Danish criminal code was previously amended in 1996 to impose a uniform standard of criminal liability on various forms of legal entities. ${ }^{99}$ That provision remains in effect today. The new provision also established the following broad standard for liability: "Criminal liability of a legal person is conditional upon a transgression having been committed within the establishment of this person by one or more persons connected to this legal person or by the legal person himself." 100 This provision appears to create two possibilities for liability: "either that a specific natural person has acted with the necessary mens rea in fulfilling the actus reus or that the legal person as such could and should have avoided the crime in question."101 The first test is simple respondeat superior liability, and liability extends to acts "in the interests of the company" of all corporate officers and employees. ${ }^{102}$ Liability under the second test does not require identifying the exact individual who performed the criminal act. ${ }^{103}$ That does not mean, however, that corporations may be strictly liable for offenses (unless the legislature so provides). ${ }^{104} \mathrm{~A}$ corporation must be shown to have acted negligently or willfully, depending on the mens rea element of the specific offense. ${ }^{105}$

Criminal Law (2003 Kluwer Law International), at II81; comments of Professor Thomas Elholm, Assistant Professor, Department of Law, University of Southern Denmark, in correspondence of July 2, 2004 and July 7, 2004, with the authors (correspondence on file with the authors).

99. Nielsen, supra note 71 , at 190 .

100. Section 27(1) of the 1996 Danish Criminal Code, quoted in Langsted et al., supra note 98 , II 82.

101. Langsted et al., supra note 98 , II 82 .

102. Nielsen, supra note 71 , at 193.

103. Langsted et al., supra note 98 , II 84.

104. Id. III 83-84 (noting that the necessary acts or omissions must have been made by a person on behalf of the corporation); Nielsen, supra note 71, at 192 ("The law is now clear: a company can only be penalized if the violation was willful or negligent.").

105. Nielsen, supra note 71, at 190, 192. There is limited literature in English on Danish and Norwegian law. From the comments of Gorm Toftegaard Nielsen, the Danish 1996 statute simply appears to be an enabling statute, directing the court to look at the specific offense for mens rea requirements. 


\section{Finland}

After years of debate on the subject, in 1995 Finland passed legislation imposing criminal liability on corporations. ${ }^{106}$ The new provision establishes a form of negligence-based liability, in which a corporation can be held liable (1) for the conduct of management, employees, or representatives, acting on behalf of the corporation, or (2) in the absence of an identifiable wrongdoer, if "the care and diligence necessary for the prevention of the offense has not been observed" by the corporation. ${ }^{107}$

\section{Switzerland}

In late 2003, Switzerland imposed criminal liability on corporations, having previously rejected such liability for doctrinal reasons. ${ }^{108}$ Swiss criminal liability is based on the concept of "subsidiary liability": a corporation can be held liable for offenses committed on its behalf only if fault

106. The new provision is contained in Chapter 9 of the revised Penal Code of Finland (743/21 April 1995). "The idea of introducing corporate criminal liabilty to the Finnish legal system was first introduced in . . the 1970s" through several legislative committees studying environmental offenses, labor offenses, and freedom of the press. M. Riihijärvi, Criminal Liability of Corporations-Finland, in Criminal Liability of Corporations, XIVth International Congress of Comparative Law, supra note 75, at 203, 211.

107. 743/1995, $\S \S 2$ and 3. English version available online at http://www.wings.buffalo.edu/law/bclc/finnish.htm. The new provision also prohibits a corporation from seeking indemnification for fines incurred from the actual wrongdoer, unless there is a basis in corporations or "foundations" law. $743 / 1995 \S 3$.

108. Peter Muller, Petite histoire législative, in La punissabilité de l'entreprise, L'Expert-Comptable Suisse, edition spéciale, no. 7, June-July 2003, 11. A limited exception existed for offenses involving fiscal (tax) evasion. Id. Opposition to corporate criminal liability also came from business quarters, who mounted stiff opposition to a proposal in the late 1980s to impose administrative criminal sanctions on corporations in the limited areas of organized crime and money laundering. Id. But the issue was addressed again in the 1990s. Switzerland was a member of several international conventions which required member states to impose deterrent sanctions on corporations for various offenses in the fields of environmental law and government corruption. Id. Although such sanctions were not required to be penal in nature, those arguing for criminal law believed that Swiss administrative measures could not fulfill the symbolic and deterrent role of penal sanctions. Id. at 11-12. 
cannot be attributed to a specific individual "because of a lack of organization within the enterprise." 109 The offense must be "in furtherance of a business activity consistent with the purpose of the enterprise," a requirement which undoubtedly will need to be defined by the courts. ${ }^{110}$ Criminal fines can range up to 5 million Swiss francs. ${ }^{111}$

In addition, a corporation may be held liable for certain serious offenses independently of the criminal liability of an individual, if the corporation has "failed to take all reasonable and necessary measures to prevent such an offense."112 Those offenses are criminal organizational crime, money laundering, bribery, corruption, and the financing of terrorism. ${ }^{113}$ This provision appears to make a corporation presumptively liable for such offenses unless it can show that it has acted with reasonable diligence to prevent their commission. This type of liability is predicated on

109. Art. 100quater of the Swiss Criminal Code, II 1, as quoted in Schellenberg Wittmer, Criminal Liability of Legal Entities, 20 No. 4 Int'l Enforcement L. Rep. 133 (April 2004). This statute appears to create a somewhat schizophrenic scheme of liability, in which a corporation may avoid liability for egregious and willful conduct by an individual acting on its behalf when a responsible actor is identified, but may be held criminally liable for unintended offenses because it negligently failed to create an organizational structure in which such an individual could be identified. Moreover, as noted by Wittmer, corporations may be able to avoid liability simply by establishing a responsible person for "specific professional functions" within the corporation. Wittmer, supra, § 3(b). Perhaps in recognition of these potential escape valves for corporations, the Swiss legislature identified a category of offenses as serious enough to merit criminal liability of the corporation independent of the liability of an individual. See infra text accompanying notes 112-14.

Prior to 2003, Swiss law criminalized the "breach of duties to supervise, instruct and select employees." Christopher Ringelmann, European Trends in Environmental Criminal Legislation, 5 European J. Crime, Crim. L. \& Just. 393, 398 (1997). In cases in which individual liability was difficult to prove, a corporation could be subject to administrative sanctions. Id. at 400 .

110. Art. 100quater of the Swiss Criminal Code, II 1, as quoted in Wittmer, supra note 109, § 2. For a further discussion of how this requirement may be interpreted, see Robert Roth, Une responsabilité sans culpabilité, in La punissabilité de l'entreprise, L'Expert-Comptable Suisse, edition spéciale, no. 7, June-July 2003, at 17, 17-19.

111. Wittmer, supra note $109, \S 2(\mathrm{e})$.

112. Art. 100quater of the Swiss Criminal Code, II 2, as quoted in Wittmer, supra note $109, \S 2$.

113. Id. $\S 2$ (b) (discussing II 2 of art. 100quater of the Swiss Criminal Code). 
management's failure to properly organize and manage the corporations's affairs. ${ }^{114}$

\section{France Adopts Corporate Criminal Liability}

Since the passage of the Napoleonic Code in 1810, France had generally "repudiated the idea that corporations, as legal fictions, could be criminally liable."115 Thus, it was a significant development in the Western European movement toward imposing corporate criminal liability when the French legislature in 1992 enacted a revised penal code that included a new statutory scheme for imposing criminal liability on corporations. ${ }^{116}$ The French legislature had previously rejected a more modest proposal put forward by a reform commission in 1974 to impose criminal liability on corporations in the area of commercial, industrial, and financial activities. ${ }^{117}$ The 1992 penal code provisions introducing corporate criminal liability were the product of years of discussion among legislators, legal scholars, and other interested parties, including representatives of the business community. ${ }^{118}$

114. One commentator has termed this "organizational failure" liability, in which liability is attributed to the corporation where management's conduct did not directly cause the offense but its failure to properly organize the corporation allowed the offense to occur. Roth, supra note 110, at 20 .

115. Coffee, supra note 70, at 23; see also Bouloc, supra note 82, at 235.

116. See Bernard Bouloc, Coup d'oeil sur la responsibilité pénale des personnes morales, Revue Lamy Droit des affairs, no. 71 (May 2004), 5, at 5 (noting that the introduction of corporate criminal liability was the most significant innovation in the new penal code); Orland \& Cachera, supra note 73, at 121-23 (observing that opposition to corporate criminal liability was finally overcome).

117. Bouloc, supra note 82 , at 237 . While the debate regarding the imposition of criminal liability on corporations in the economic field was occurring, the French government was increasingly imposing civil and administrative restrictions on corporations in the economic sphere. In 1972, 1973, and 1974, the French legislature, through a series of laws, "began to intervene" to protect consumers from "abuses" of market position committed by distributers. See id. at 237-38. In 1977, France's Economy Minister was given the power to impose sanctions on corporations for violations of consumer protection and market competition laws. See id. at 237. And as noted supra note 84 , by the early 1980 s, the French government had imposed quasi-criminal liability on corporations in a few areas.

118. See infra note 261. 
The introduction of comprehensive criminal responsibility on corporations brought forth "reservations and criticism" from the corporate classes. ${ }^{119}$

1. The Statutory Basis for Criminal Responsibility of Legal Entities, Including Corporations

The basis for corporate criminal liability in French law is codified in article 121-2 of the new French penal code, which states: "Juridicial persons, with the exception of the State, are criminally liable for the offenses committed on their account by their organs or representatives ... in the cases provided for by statute or regulations." ${ }^{20}$ Article 121-2 further provides the "criminal liability of legal persons does not exclude that of the natural persons who are perpetrators or accomplices to the same act." 21 This clause appears to respond directly to the critique-raised during the early legislative process that led to the adoption of the 1992 penal code-that corporate liability could be used to shield corporate officers and directors from criminal liability. ${ }^{122}$

\section{The Prerequisites for the Imposition of Criminal} Liability on Legal Entities

There are three basic requirements for liability to be imposed under article 121-2. First, the French legislature must have enacted a substantive criminal offense which

119. Bouloc, supra note 82 , at 237-38. In response to the enactment of corporate criminal liability, the National Association of French Employers issued a study addressing the new legal implications of such liability for corporations. See Pierrick B. Le Goff, The French Approach to Corporate Liability for Damage to the Environment, 12 Tul. Euro. \& Civ. L.F. 39, 39 n.117 (1997).

120. Art. 121-2, reprinted in Recueil Dalloz, Code Penal (Dalloz 2004). Article 121-2 is available in English at http://www.legifrance.gouv.fr.

121. Id.

122. Gerard Couturier, Répartition des responsabilités entre personnes morales et peronnes physiques, 111 Revue des Societes (Dalloz, April-June 1993), at 307. See Bouloc, supra note 116, at 5, 8 (noting that the Court of Cassation has stated that personal liability may exist coterminously with corporate liability, without the need to establish a distinct fault on the part of either the individual or the corporation not committed by the other). 
the corporation contravened. ${ }^{123}$ Second, actual criminal responsibility for the offense must lie in the conduct of a corporation's representatives or its organs. ${ }^{124}$ Third, the acts on which criminal liability is predicated must have been committed for the benefit of the corporation. ${ }^{25}$ The Criminal Chamber of the Court of Cassation is still clarifying the second and third of these requirements - that the criminal act be done by certain representatives or units ("organs") of the corporation and that the act be done for the corporation's benefit. ${ }^{126}$ The scope of corporate liability inevitably turns on how the Court of Cassation chooses to define a "representative" and an "organ."

\section{a. A Corporation's "Representative"}

The term "representative" means a high ranking officer or an agent or employee with delegated authority from a corporate officer. Therefore, criminal offenses committed by such persons on behalf of the corporation will give rise to criminal liability. ${ }^{127}$ The legislature, when enacting article 121-2, did not originally envisage that a corporation could be held criminally liable based on the conduct of lower level employees. ${ }^{128}$

123. Le Goff, supra note 119 , at 60 ; Orland \& Cachera, supra note 73 , app. B, at 141.

124. As one commentator has stated, the natural person is the obligatory means toward imposing criminal liability on a corporation. Jacques Leroy, Droit Penal General, II 444, at 287 (Librarie Générale de Droit et de Jurisprudence 2003) ("La personne physique est, ainsi, le passage obligé de la mise en oeuvre de la responsibilité pénale des personnes morales.").

125. Art. 121-2 ("offenses committed on their account"). However, actions taken primarily for the benefit of the actor, as opposed to the corporation, cannot be the basis for corporate liability. Bouloc, supra note 82, at 240. Obviously, this test is one that is forever subject to difficulty at the margins, when the intent of the individual actor and the interests of the corporation merge. See Bouloc, supra note 116 , at 5,7 .

126. See Bouloc, supra note 82 , at 240 (discussing ambiguity of the term "representative"). Professor Coffee has noted that the degree of managerial involvement, the role of collective entity knowledge, and the absence of negligence remain undefined factors under article 121-2. Coffee, supra note 70, at 24 .

127. Leroy, supra note 124 , II 447 , at 288-89.

128. Mireille Delmas-Marty, supra note 72 , at 304 ; Bouloc, supra note 82 , at 
However, it is unclear whether the legislature intended for the corporation to be liable for offenses requiring a showing of intentional fault where it can be shown that a corporation's representative had the necessary state of mind for the offense (through intent, knowledge, or willful blindness), but the criminal act was committed by another person without immediately delegated authority. Much to the dismay of some scholars, the Court of Cassation initially rejected such an approach, instead requiring that full criminal responsibility lie with a corporate representative in order for criminal responsibility to be imputed to the corporation. ${ }^{129}$ Since then, however,

240 .

129. See Leroy, supra note 124, II 447 (citing Cass. crim., 11 May 1999, Droit pénal, comm. no. 140 (deuxième espèce), note M. Vérnon; Cass. Crim. 26 June 2001, Bull. crim., no. 161). Delmas-Marty, in an article published after the passage of article 121-2 but before its implementation, argued that it was possible to interpret the new law as separating the "moral element" of an offense from the "material element," and imposing liability on the corporation for the conduct of lower level employees when the "moral element" (i.e., fault or state of mind) of the offense lay with a corporation's representative or its board of directors. DelmasMarty, supra note 72, at 304. Another commentator noted that a lower court in Lyon originally took such an approach, but the Court of Cassation quickly noted its disagreement and required the establishment of personal liability as a predicate for corporate liability. Jean-Claud Planque, Note, Influence de loi du 10 juillet 2000 sur la responsabilité pénale des personnes morales, Commentaires Dalloz, no. 6, at 514, 515-16 (citing Cass. Crim., 2 Dec. 1997, Bull. crim., no. 408; Cass. Crim. 7 July 1998, Bull. crim., no. 216). This commentator has also called for the legislature to clarify article 121-2 so that corporate criminal responsibility is autonomous of personal responsibility. Id. at 518. See also Leroy, supra note 124, II 447, at 288-89 (suggesting that corporate fault should not simply "ricochet" off of personal liability, and proposing the imposition of criminal liability on a corporation in cases where it is poorly structured so as to permit the commission of an offense). See also Circular of May 14, 1993, Commentaries on Legislative Provision of the Nouveau Code Pénal and on Provisions of Law of December 16, 1992, as translated in part in Orland \& Cachera, supra note 73, at 139-62 (noting that "a personne morale might be found criminally responsible in the absence of deliberate willfulness of its corporate bodies or officers, and this is contrary to the 1978 proposal submitted by the Revision Committee. Personnnes morale might, indeed, be prosecuted for offenses of negligence or imprudence ...."). But see Circular of May 14, 1993, as translated in Orland \& Cachera, supra note 73, at 148 ("[I]t can be said that a personne morale can be held criminally responsible as a main perpetrator, when its corporate bodies or officers have . . carried out, as a main perpetrator, the moral and material elements of the offense."). The Circular was drafted "under the auspices of the Ministry of Justice in consultation with a task group composed of judges, law professors, lawyers and police 
the Court of Cassation has relaxed this rigid requirement in certain cases. ${ }^{130}$

A July 2000 amendment to article 121-3 of the new penal code effectively expanded the scope of liability for criminal negligence under article 121-2. The July 2000 amendment made natural persons indirectly liable for negligence-based offenses because of their failure to take measures to prevent the offense (by deliberately ignoring a duty of care or other statutory obligation imposed on them). ${ }^{131}$ Criminal negligence may now be imputed to a corporation because of the negligence of one of its officers, even when that person was not personally involved in the offense. The Court of Cassation, however, still appears to require that actual negligence on the part of a corporate representative is established. ${ }^{132}$

representatives." Orland \& Cachera, supra note 73, at 137. A Circular, which is not a legislative document, may not be cited by a French court as the legal basis for a decision. Id. at 138.

130. Planque, supra note 129, at 516 (citing J.-H. Robert, Chron. dr. pénal, JCP 2000, I, no. 289).

131. Prior to its amendment, article 121-3 provided:

A misdemeanour also exists, where the law so provides, in cases of recklessness, negligence, or failure to observe an obligation of due care or precaution imposed by any statute or regulation, where it is established that the offender has failed to show normal diligence, taking into consideration where appropriate the nature of his role or functions, of his capacities and powers and of the means then available to him.

The July 2000 amendment added the following paragraph:

In the case as referred to in the above paragraph, natural persons who have not directly contributed to causing the damage, but who have created or contributed to create the situation which allowed the damage to happen who failed to take steps enabling it to be avoided, are criminally liable where it is shown that they have broken a duty of care or precaution laid down by statute or regulation in a manifestly deliberate manner, or have committed a specified piece of misconduct which exposed another person to a particularly serious risk of which they must have been aware.

Art. 121-3, as enacted through Act no. 1996-393 of 13 May 1996 art. 1 Official Journal of 14 May 1996; and amended by Act no. 2000-647 of 10 July art. 1 Official Journal of 11 July 2000. English translation available at http://www.legifrance.gouv.fr.

132. An October 2000 decision of the Court of Cassation, interpreting article 121-3 and article 121-2, as well as worker safety laws, held that a corporation could be criminally liable for the injury to a worker caused by the conduct of the director of a factory if it could be shown that the corporate representative was 


\section{b. A Corporation's "Organ”}

The conduct of "organs" of a corporation may also be imputed to the corporation to establish criminal responsibility. An "organ" is an organization within the corporation that is formally identified in the French corporations law, such as its board of directors or its shareholders (e.g., acting through a shareholder meeting). ${ }^{133}$ The extent of liability that may be imposed on a corporation because of the actions of one of its organs appears to turn on the question of whether decision makers within the organ must themselves be identified in the commission of the crime, or whether it is enough to identify the collective actions of the persons within that unit as responsible. Once again, the Court of Cassation took a narrow reading of the code, and was reluctant to permit liability without identifying culpable individuals within the corporate organ. ${ }^{134}$ Under this narrow approach, even where a board of directors is collectively responsible for the commission of an offense, liability will not be imputed to the corporation unless one of the board's members is found to be personally responsible for the commission of the offense. ${ }^{135}$ This interpretation is so constrained that it renders the concept of "organ" nearly coextensive with the concept of "representative."

personally negligent under article 121-3. See Jean-Claude Planque, supra note 129, at 515-16 (citing Cass. crim., 24 Oct. 2000, Bull. crim., no. 308). Planque has suggested that the amendment to article 121-3 creates tension with the basic theory of liability under article 121-2, as originally articulated by the Court of Cassation, which requires criminal responsibility to lie entirely with a natural person who acts on behalf of the corporation. See generally id.

133. Leroy, supra note 124 , III $446-447$, at $288-89$. The term is highly problematic, in that it appears to include persons who can be representatives but may not include certain board, managerial, and shareholder bodies in more modern French corporate law. Leroy, supra note 124, II 447, at 288-89.

134. Leroy, supra note 124, II 446, at 288 (citing Cass. crim., 11 May 1999, Droit pénal, comm. no. 140 (deuxième espèce), note M. Vérnon).

135. See Leroy, supra note 124, II 446, at 288. However, one 1998 decision of the Court of Cassation suggested that it may be possible to impose liability even in the absence of a clearly identified wrongdoer within the corporation if the nature of the offense and the circumstances of its commission make its imputation to the corporation reasonably certain. Id. at 288 (citing Cass. crim., 1 Dec. 1998, Bull. Crim., no. 325). 


\section{Substantive Corporate Offenses under French Law}

Although the formal elements of criminal liability under article 121-2 remain uncertain, the French legislature has continued to expand the list of substantive offenses for which a corporation may be liable. When first proposed through a legislative reform commission in 1974, criminal liability was originally to be imposed in the areas of commercial, industrial, and financial activities, and quasi-criminal liability was imposed in these areas before $1992 .{ }^{136}$ The newly enacted article 121-2, however, by operation of other parts of the French code, reaches many more substantive areas, including antitrust offenses and environmental crimes. ${ }^{137}$ By 2001, liability was expanded to include commercial torts, unsafe working conditions, and even new areas such as homicide, rape, and human rights abuses caused by corporate actors. ${ }^{138}$

\section{Statutory Sanctions for Corporate Offenders}

Another important feature of the new French law is that it provides an expansive list of statutory criminal penalties. In most cases, these will be monetary penalties five times the rate for natural persons committing the same

136. See supra notes 84 and 117 and accompanying text.

137. See Le Goff, supra note 119, at 60-63 (discussing interplay of article 121-2 with environmental laws); id. at 60 (noting application of article 121-2 to antitrust and worker safety laws); Orland \& Cachera, supra note 73, at 141-46 (generally listing substantive corporate criminal offenses).

138. Olivier Sautel, La Mise en oeuvre de la responsabilité pénale des personnes morale: entre litanie et liturgie, Le Dalloz 2002, no. 14, at 1147; see also Revue de science criminelle et de droit pénal comparé (4), Dalloz Oct.-Dec. 2001, at 843 (reviewing new legislative enactments of substantive offenses); Orland \& Cachera, supra note 73, at app. B, 141-46 (listing offenses). This expansion of substantive liability has caused one commentator to argue that French corporate criminal liability has become "totally incoherent" and to recommend that the legislature adopt a general system of criminal liability that makes criminal corporate liability more "rationale" and "predictable." Sautel, supra, at 1147-48. Playing on the French term for "juridicial person" ("personne morale"), Sautel has suggested that the expansion of substantive corporate liability has "left no doubt" that "personnes morales have become personnes immorales capable of killing, injuring, and raping." Id. at 1148. 
offense, with greater monetary penalties for recidivist conduct. ${ }^{139}$ The penal code also includes some other penalties available to a court in extraordinary circumstances. These include judicial supervision of a corporation's affairs for a period of five years (e.g., the ability to enter a contract), a five-year ban on the issuance of publicly financed corporate bonds, limitations on the use of checks and credit to make payments, confiscation of assets which facilitated or were gained from the offense, posting of notices throughout the media, publication of the judgment in a registry, and, in extreme cases, dissolution of the corporation. ${ }^{140}$

\section{Movement Toward Corporate Criminal Liability in Germany}

Unlike France, Germany has not overcome its longstanding opposition to the imposition of criminal liability on artificial entities. Interestingly, resistance to the imposition of corporate liability appears to come from scholars and jurists more concerned with the "purity" of the notion of blame and fault in the criminal law than with the effects on corporations of imposing criminal-style sanctions on them. ${ }^{141}$ Today, corporate misconduct still is addressed through administrative sanctions imposed by

139. Orland \& Cachera, supra note 73 , app. A at 129, 132, 135 (citing articles 131-38, 131-41 and 132-12 through 132-15 of the French penal code); Bouloc, supra note 82 , at $246-47$.

140. Orland \& Cachera, supra note 73, app. A at 130 (citing article 131-39 of the French penal code); Bouloc, supra note 82, at 247; Le Goff, supra note 119, at 60-61 (noting the establishment of "a specific register containing the criminal record of legal entities" and other offenses designed to compensate for the fact that corporations "cannot be imprisoned"). Cf. Michael Faure \& Günter Heine, Environmental Criminal Law in the European Union (Max Planck Institute 2000), at 127 (noting that more severe sanctions against corporations are "substitutes for imprisonment" and therefore should not be available unless a prison sentence could be imposed on a person guilty of the same offense).

141. Mark Pieth, International Developments, in Criminal Responsibility of Legal and Collective Entities, supra note 70, at 113, 116 ("[T] he fear [of German scholars] is that essential safeguards of both substantive and procedural law would be put at risk" from derogations of the "principle of personal guilt or blameworthiness."). 
administrative bodies and supervised by criminal courts. Corporations can face fines of millions of euros and other sanctions that are quasi-criminal in status, ${ }^{142}$ such as confiscation of illicit gains or property used to facilitate offenses. ${ }^{143}$ Because of German law's emphasis on classifications, severe sanctions may be imposed on corporations in administrative proceedings as long as they are classified formally as "monetary fines" imposed for "order violations," rather than "punishments" for "crimes." "144

Although corporate officers and directors are subject to criminal liability for their own $\operatorname{acts}^{145}$ and the acts of corporate subordinates, ${ }^{146}$ some German prosecutors and academics have noted that corporations have learned to structure transactions so as to avoid the imposition of liability on directors and officers. ${ }^{147}$ Others have noted that

142. Roland Hefendehl, Corporate Criminal Liability: Model Penal Code Section 2.07 and the Development in Western Legal Systems, 4 Buff. Crim. L. Rev. 283, 286 (2000); Heine, supra note 72, at 174-75.

143. H.J. Hirsch, La Criminalisation du Comportement Collectif-Allemagne, in Criminal Liability of Corporations, XIVth International Congress of Comparative Law, supra note 75, at 31,62-64. Sanctions are increasingly common in the areas of commercial and environmental law. Id. at 32. Some administrative violations may even carry sanctions such as restrictions on activities, revocations of licenses and concessions. Id. at 48. In limited cases, when a corporation's conduct transgresses fundamental criminal law or other law and poses a danger to society, it may be subject to dissolution. Id. at 47.

144. See Dubber, supra note 73 , at $17 \&$ n. 71 .

145. German prosecutors attempted to pursue sanctions against four directors of the former Mannesmann Corporation for approving a pay-out package of $\$ 66$ million for senior management in the Vodaphone takeover of Mannesmann. Mark Landler, Deutsche Bank Executive to Have His Day in Court, N.Y. Times, October 18, 2003, at C3. However, a German court acquitted the directors on July 22, 2004. Mark Landler, Corporate Pay Case Ends in Acquittal, N.Y. Times, July 23, 2003, at W1.

146. Heine, supra note 72 , at 177 . Cf. Jurgen Meyer, Comments on Developments in Germany, in Criminal Responsibility of Legal and Collective Entities, supra note 70, at 129, 129 (noting that criminal law provides for individual liability for corporate offenses in the areas of fraudulent tender offers, capital investment fraud, tax evasion, breach of export laws, manufacture and distribution of products harmful to health, industrial environmental pollution and dumping, and money laundering).

147. Klaus-Dieter Benner, A Description of the Legal Practices in Germany, in Criminal Responsibility of Legal and Collective Entities, supra note 70, at 53, 5455. Because of this liability scheme, German criminal law may fail to reach 
the increasing size of large corporations makes it difficult to identify the individual culpable of the offense. ${ }^{148}$ Moreover, German law "limits the class of natural persons whose acts may make the corporation liable" under administrative or civil law to its legal representatives and directors ${ }^{149}$ so identification of the person who committed the offense is unlikely to result in liability of the corporation. Criminal liability that may ultimately fall on a lower-level employee for his own criminal conduct does little to deter corporate misconduct. When an employee is convicted of an offense and is fined, the corporation may reimburse the fines, further diluting the effect of the criminal law. ${ }^{150}$

It is not surprising, then, that some German prosecutors and scholars believe that individual criminal liability does not obviate the need for the imposition of criminal liability on corporations. ${ }^{151}$ German scholars have

corporations engaged in crimes ranging from financial fraud schemes to the dumping of toxic wastes. Id.; Harald Kolz, Aspects of Legal Practice in Germany, in Criminal Responsibility of Legal and Collective Entities, supra note 70, at 67, 67-68. German academics have traditionally played an important role in the development of the criminal law. See Dubber, supra note 73, at 7-8.

148. Hirsch, supra note 143 , at 33 . One commentator noted that, "[e]ven in cases where the prosecuting authorities have established without a doubt that a criminal offense has been committed by and in the interest of a company, illegal dumping of waste or water pollution for example, complex organisational structures and company hierarchies mean that it is often not possible to ascertain with sufficient certainty who the individual offender is and to call them to account. To an increasing degree, we are seeing an 'organised' or structural lack of individual responsibility." Meyer, supra note 146, at 130 . This commentator further notes that an increasing number of criminal prosecutions for environmental offenses are being dismissed by the prosecutor's office. Id.

149. Coffee, supra note 70, at 23.

150. Gerd Eidam, Aspects of Legal Practice in Germany, in Criminal Responsibility of Legal and Collective Entities, supra note 70, at 59, 64-65; Hirsh, supra note 143 , at $33 \&$ n.9 (noting that the corporation's partial reimbursement of fines incurred by an employee by a corporation "does not constitute a connivance at evasion" under German law).

151. See, e.g., Benner, supra note 147, at 56-58 (noting German companies find it cheaper to pay fines incurred than to comply with the law); Hefendehl, supra note 142, at 283-84 (noting that European scholars may be over-emphasizing doctrinal opposition to corporate liability and that corporate misconduct is increasingly the subject of concern among scholars); Meyer, supra note 146, at 132 (proposing corporate criminal sanctions similar to those proposed by the EU's 
proposed different theoretical models for the imposition of criminal liability. Some have suggested an alternative to the Anglo-American respondeat superior theory of liability, and have examined an "organizational fault" model. ${ }^{152}$ Under this model, liability is premised on the identification of a deficiency in the organizational structure that caused the offense. ${ }^{153}$ While this would address the problem raised by the conscious attempt of a corporate hierarchy to turn a blind eye toward misconduct at lower levels in the organization, the doctrine is broader, and reaches negligent failure by management in supervising the corporation. The corporation would be liable for the commission of an offense if its structure is deemed inadequate to respond to the risks created by its operational conduct. ${ }^{154}$ Proponents favoring this model of liability argue that corporate misconduct is not always the result of a deliberate managerial choice to ignore the law but the result of several acts by lower level employees and organizations within the corporation, "the sum of ... which constitute the offense."155 They also suggest that the greater social injury caused by corporate misconduct requires a conceptual approach to corporate crime that is not constrained by the identification of a responsible person, as is required by more traditional theories of liability. ${ }^{156}$

At some point, one other feature of German criminal law may also come into play in the debate over whether to create corporate criminal liability. The theory of positive general prevention, which has become the dominant theory of punishment in Germany, defines the function of criminal

1988 proposal and available in French law, including publication of judgment, prohibition on advertising, and dissolution).

152. Heine, supra note 72 , at 182-83; Hefendehl, supra note 142 , at $297-98$ (discussing Bernd Schünemann's proposal to abandon the principle of personal guilt for corporate criminal liability).

153. Heine, supra note 72 , at $182-83$.

154. Heine, supra note 72 , at 182-83; Hefendehl, supra note 142 , at 297-98.

155. Eidam, supra note 150 , at 65 .

156. Hefendehl, supra note 142, at 293 (noting Schünemann's view that the "collective act patterns" of corporations are inconsistent with individual guilt, and that the "danger to legal rights protected by the criminal law increases in the field of" corporate conduct). 
punishment as "bolstering the lawabidingness" of the population. ${ }^{157}$ Although this theory has traditionally been focused on individuals, it might also be extended to corporate persons, as a means of enhancing their "general legal consciousness."'158 This theory seems to bear some resemblance to the arguments of American theorists that criminal law serves an expressive or social meaning function. ${ }^{159}$

\section{E. European Transnational Proposals for Corporate Criminal Liability}

In recent years, transnational European organizations have begun to recommend that member states impose criminal or quasi-criminal liability on corporations for specific types of offenses through the member states' own legal regimes. Some of the developments from two key organizations, the Council of Europe and the European Union ("EU") will be discussed here, because they provide insight into a strain of influential European thought, and may anticipate the direction of corporate criminal liability in the European member states (whose representatives comprise the governing bodies of these organizations). ${ }^{160}$ It

157. See Dubber, supra note 73 , at 20 .

158. See id. at 21.

159. These arguments are developed supra at text accompanying notes 61-63. Note, however, that positive general prevention developed independently of, and partially in response to, Karl Binding's norm theory. See Dubber, supra note 73, at $18-19$.

160. We will discuss some of the recommendations of the Council of Europe and the European Union. The Council of Europe is a loose association of European states across the continent. From time to time, the Council will produce conventions that attempt to standardize member states's social and legal practices. See http://www.coe.int ("about the Council of Europe"). These conventions are legally binding on member states that ratify them, although many ratify them with reservations. See id. ("about conventions").

The European Union ("EU") is a smaller group of European nations that form a common economic market to standardize economic policies, national fiscal policies, and trade policies. Increasingly, the EU is attempting to standardize policies in the areas of the environment and in legal spheres affecting economic relations, such as intellectual property and corporate governance. The EU is also attempting to address criminal activity of concern to all member states, such as 
should be noted, however, that the proposals for corporate liability discussed in this section have yet to be fully implemented by member states.

1. Proposals of the Council of Europe

\section{a. Proposal for Standardization of Enterprise Criminal Liability}

In 1988, the Council of Europe passed a recommendation that member states study the need to standardize criminal "enterprise" liability among the member states. ${ }^{161}$ The Council noted that its proposal was in response to several factors: the "considerable damage" caused by "criminal offences committed in the exercise of the activities of enterprises," the difficulty in identifying responsible individuals within the corporation due to the complexity of the corporate structure, and the desirability of placing criminal responsibility on the corporation benefitting from illegal activity. ${ }^{162}$

The Council's recommendation was significant in three respects. First, the Council "favor[ed] a negligence-based approach to corporate criminal liability." 163 The Council recommended imposing liability for offenses committed in the course of corporate activities, unless it could be shown that "management [was] not implicated in the offence and [had] taken all the necessary steps to prevent its

financial crimes, foreign exchange crimes, and political corruption of EU bodies. Policies and laws, in the form of directives and regulations, are proposed by the EU's executive body (the Commission), and adopted by its legislative bodies (the European Parliament and the Council of the European Union). The Parliament and Council can modify and reject proposals of the Commission. Laws and regulations in various legal, social, and economic spheres require member states to harmonize or modify their laws consistent with the relevant directive or regulation. See http://www.europa.eu.int/institutions.

161. See Liability of Enterprises for Offenses, Recommendation No. R (88) 18, adopted by the Committee of Ministers of the Council of Europe on 20 October of 1988, available at http://www.coe.int.

162. Id.

163. Coffee, supra note 70 , at 35 . 
commission." 164 Second, as would later appear in article 121-2 of the new French penal code, the Council explicitly noted that corporate criminal liability should not displace the liability of natural persons, particularly managers. ${ }^{165}$ Third, the Council's recommendation proposed sanctions on corporations that included alternatives to monetary fines, such as the removal of managers, the appointment of "provisional caretaker management" by a court, disgorgement of illegal gains and property used to facilitate offenses, prohibition on public contracts, denial of public fiscal benefits, prohibition on advertising goods or services, publication of the judgment, and closure or winding-up of the corporation. ${ }^{166}$ The Council's 1988 recommendation has not been adopted by the member states, possibly because doing so would have required them to address the doctrinal resistance in their legal systems to the imposition of corporate criminal liability. As we have noted, such doctrinal resistance continues in states such as Germany and Italy. ${ }^{167}$

\section{b. Proposal for Corporate Liability for Environmental Offenses}

Subsequent proposals for corporate liability targeted specific fields of social and economic activity. In 1998, the Council of Europe approved for signature by member states the Convention on the Protection of the Environment through Criminal Law. Articles 2 and 3 of the convention identify a series of intentional and negligent offenses involving unlawful discharges into the air, soil, and water, and unlawful manufacture, transportation, and storage of hazardous materials, among other offenses. ${ }^{168}$ Article 9 of

164. Liability of Enterprises for Offenses, Recommendation No. R (88) 18, supra note 161 , IITI $1-5$.

165. Id. II 5.

166. Id. II 7. See also Möhrenschlager, supra note 74, at 95-96.

167. See supra notes 75 and 141, and accompanying text.

168. European Treaty Series No. 172, Convention on the Protection of the Environment through Criminal Law, 4 Nov. 1998, arts. 2 and 3, available at http://www.coe.int. 
the convention recommends that member states impose criminal liability on corporations, but it also gives them the option of imposing administrative sanctions. ${ }^{169}$ Individual criminal liability is not displaced. ${ }^{170}$ The preamble to the convention notes that "imposing criminal or administrative sanctions on legal persons can play an effective role in the prevention of environmental violations."171 One commentator has noted that the convention's proposal for corporate criminal liability appears influenced by the new French law, in that it makes an entity criminally liable for acts committed by its representatives or its "organs."172 France, Germany, and eleven other member states have signed the convention, but only Estonia has ratified it. ${ }^{173}$

\section{c. Proposal for Corporate Liability for Offenses Involving Corruption}

In 1999, the Council of Europe put forward for signature a Criminal Law Convention on Corruption. The Convention identifies a series of offenses related to bribery of domestic and foreign public officials, including officials in international organizations. ${ }^{174}$ Article 18 states that signatory parties are to adopt measures "necessary to ensure that legal persons can be held liable for the criminal offences of active bribery, trading in influence and money laundering." ${ }^{175}$ Like the convention on the environment, the convention on corruption predicates corporate liability on the acts of a representative or organ of the corporation. $^{176}$ But the convention on corruption expands the scope of corporate liability to cases in which the "lack of supervision or control" by corporate management makes

169. Id. art. 9; Ringelmann, supra note 109 , at 400.

170. European Treaty Series No. 172, supra note 168, art. 9.2.

171. European Treaty Series No. 172, supra note 168, at preamble.

172. Möhrenschlager, supra note 74, at 103.

173. http://conventions.coe.int (convention on environmental law).

174. European Treaty Series No. 173, Criminal Law Convention on Corruption, 27 Jan. 1999, arts. 2-12.

175. Id. art. 18.

176. Id. art. 18 
the offense possible. ${ }^{177}$ Individual criminal liability is not displaced. ${ }^{178}$ Although the title of the Convention refers to criminal law, it permits countries to use quasi-criminal or administrative sanctions, rather than criminal sanctions. Parties are required to adopt "effective, proportionate and dissuasive criminal or non-criminal sanctions" against corporate offenders who commit any of the identified offenses. ${ }^{179}$ The Convention has been ratified and entered into force by thirty countries. Significantly, however, France, Germany, Italy, and Switzerland have not ratified it, and Spain has not even signed it. ${ }^{180}$

\section{Proposals of the European Union}

\section{a. Administrative Liability for Anti-competition Offenses}

One of the first European transnational agreements to impose liability on corporations was the 1957 Treaty of Rome, which established a common market for goods and services by the 1960s that was known as the European Economic Community (comprised originally of Belgium, Germany, France, Italy, Luxembourg, and the Netherlands). The EEC is the precursor to today's European Union. Articles 81 and 82 of the Treaty of Rome, as amended, prohibit anti-competitive conduct within the common market. ${ }^{181}$ Specifically, article 81 prohibits restrictive agreements and concerted activities, and article 82 prohibits abuses of dominant market positions. ${ }^{182}$ The

177. Id. art. 18.2. This standard is similar to the standard in the Council's 1988 proposal, which recommends an examination of whether management acted negligently. See supra text accompanying note 164 .

178. Id. art. 18.3 .

179. Id. art. 19.

180. http://conventions.coe.int (convention on corruption).

181. As originally enacted, articles 81 and 82 were numbered articles 85 and 86. They were renumbered by the Treaty of Amsterdam Amending the Treaty on European Union, the Treaties Establishing the European Communities, and Certain Related Acts, signed on 2 October 1997, and available at http://www.europa.eu.int/eur-lex/en/treaties.

182. James S. Venit, EU Competition Law_Enforcement and Compliance: An 
EU's executive body, the Commission, is empowered to investigate companies engaging in anti-competitive conduct, to enjoin conduct, and to impose heavy sanctions. ${ }^{183}$ Sanctions have become increasingly higher, with one sanction reportedly exceeding US $\$ 300$ million on a company found to have engaged in an illegal marketsharing cartel. ${ }^{184}$

Although the sanctions imposed by the Commission are civil fines, some commentators have suggested that the sanctions are so severe as to be criminal in nature. ${ }^{185}$ Regardless of how one characterizes them, it is fair to suggest that the role and nature of these sanctions appear to have influenced member states's attitudes regarding the imposition of penal liability on corporations under their own legal regimes. Even in countries that continue to resist the imposition of corporate criminal liability, such as Italy and Germany, quasi-criminal administrative sanctions that follow the EU model have been introduced. ${ }^{186}$

\section{b. Council Framework Decision Regarding Environmental Offenses}

The Council of the European Union has adopted a "Framework Decision" requiring member states to impose

Overview, 65 Antitrust L.J. (Fall 1996), at 81, 82-84.

183. Id. at $84-85$.

184. Id. at 86 .

185. See Möhrenschlager, supra 74, at 98 (noting that some scholars have argued that the fines, although deemed civil, resemble criminal sanctions and therefore are outside the scope of the Commission's authority).

186. Italy, for example, has replicated EU anti-competition sanctions through passage of a 1990 law, with an administrative authority empowered to impose fines on corporations. One Italian scholar, commenting on the Italian anticompetition fines, noted that "we cannot escape the structural analogy between these fines and those which are envisaged for corporations in the penal systems of common law. On the one hand, this indicates that types of direct responsibility for collective bodies exist also in countries which are still tied to a traditional negation of the criminal capacity of corporations. On the other hand, this analogy expresses the uncertainty of labeling the nature of sanctions, thereby confirming the necessity of reconsidering the bases of criminal responsibility for collective subjects." Militello, supra note 75, at 183. 
liability on legal entities for environmental offenses. ${ }^{187}$ The Framework explicitly cites the Council of Europe's 1998 convention on the environment and borrows from it in several respects. First, it identifies a series of intentional and negligent offenses regarding unlawful discharges and production, storage, transportation, etc., of hazardous materials. ${ }^{188}$ Second, it recommends that member states adopt measures to impose criminal liability on legal persons based on acts of their representatives and organs. ${ }^{189}$ The Council's Framework also recommends liability in cases where there is a lack of supervision or control in the corporation that "made possible the commission" of the offense. ${ }^{190}$ Although the Framework decision encourages the imposition of criminal liability, it does not appear to be mandatory, since member states have the option of imposing criminal or civil fines and other "effective, proportionate and dissuasive sanctions," such as disqualification from certain industrial or commercial activities, or even judicial supervision and winding-up of the corporation. ${ }^{191}$ Third, the Framework Decision states that corporate liability should not "exclude criminal proceedings against natural persons who are perpetrators, instigators or accessories" in the identified offenses. ${ }^{192}$

The Council adopted its Framework Decision in lieu of a directive proposed for its adoption by the Commission. The Commission's proposed directive appears to leave member states with less discretion in imposing criminal liability on legal persons, which may have been one reason

187. Council Framework Decision 2003/80/JHA of 27 Jan. 2003 on the Protection of the Environment Through Criminal Law, in Official J. Eur. Union, at L 29/55.

188. Compare id. arts. 2 and 3 with ETS 172, supra note 168, arts. 2 and 3.

189. Compare Framework Decision 2003/80/JHA, supra note 187, art. 6, with ETS 172, supra note 168, art. 9.

190. Framework Decision 2003/80/JHA, supra note 187, art. 6.2. Similarly, the Council of Europe's convention directs member states to impose negligent-based liability on corporations for environmental offenses. ETS 172, supra note 168, arts. 3 and 9.

191. Framework Decision 2003/80/JHA, supra note 187, art. 7.

192. Compare Framework Decision 2003/80/JHA, supra note 187, art. 6, with ETS 172, supra note 168, art. 9.2. 
the Council ultimately declined to adopt it. ${ }^{193}$ In response, the Commission took the unusual step of asking the European Court of Justice to annul the Framework Decision on the basis that the Council did not rest its action on the appropriate legal grounds found in EU treaty law. ${ }^{194}$ It is unclear why the Council adopted a Framework Decision after rejecting the proposed directive. It is possible, however, that the public's outrage at the oil spill in November 2002 caused by the Prestige tanker off the coasts of Spain and France ${ }^{195}$ pressured the Council to adopt some type of measure with respect to corporate environmental offenses.

\section{c. Proposal for a Directive Involving Corruption Offenses}

In 2001, the Commission of the European Union recommended that member states adopt corporate criminal liability to combat fraud and "corruption" (i.e., bribery) directed at the use of European Union funds and money

193. See generally Proposal for a Directive of the European Parliament and of the Council on the Protection of the Environment through Criminal Law of March 13, 2001, COM (2001) 139, as amended on September 30, 2002, COM (2002) 544. The preamble to the proposed directive states: "Although Community law may, in certain cases, already require Member States to provide for criminal penalties with regard to article $10 \mathrm{EC}$, currently there is no Community provision which requires expressly this type of sanction. As a consequence, there is not only a lack of certainty of the law with regard to the Member States's obligations to provide for criminal penalties, but there is no minimum standard or acquis communautaire with regard to offences to the detriment of the environment."

194. The Legislative Observatory of the EU, at http://www.europarl.eu.int (Identification reference no. COD/2001/0076). According to the Commission, the appropriate legal basis for establishing criminal penalties for environmental law community-wide is article 175 of the Treaty establishing the European Community, referred to as the "first pillar" of Community law. The Framework Decision, however, rests on title VI of the Treaty on European Union relating to judicial cooperation in criminal matters, referred to as the "third pillar." The Commission expressed doubt that the "third pillar" provides an appropriate "legal basis for requiring Member States to provide for criminal penalties for environmental offences." Id. (entry of March 3, 2003).

195. France Targets Tanker Spill Culprits, BBC News Europe, January 2, 2003, at http://news.bbc.co.uk/1/hi/world/europe/2622855.stm. 
laundering. ${ }^{196}$ The Commission noted that the "sheer extent" of injury to the Community's financial interests from such conduct made tougher sanctions "a matter of urgency."197 The Commission's proposal encompasses liability based on negligence. Pursuant to the proposal, corporate liability exists (1) when such offenses are committed by a representative of the corporation or person with authority to act on behalf of the corporation or (2) when the offense resulted from a lack of supervision or control within the corporation. ${ }^{198}$ Obviously aware of the continued resistance among some member states toward imposing full corporate criminal liability, the Commission stated that "changes need to be made ... to national legislation, so that bodies corporate can be held responsible for acts of fraud, active corruption and money laundering ... that damage or threaten to damage the financial interests of the Community." 199 Although the proposed directive expresses a strong preference for the criminalization of such conduct, ${ }^{200}$ it permits member states to adopt non-criminal sanctions against corporations, so long as they are "effective, proportionate and dissuasive."201 With respect to natural persons who perpetrate corruption offenses, the directive states that corporate liability should not "exclude criminal proceedings against natural persons who are perpetrators, instigators or accessories in the fraud, active corruption, or money laundering." 202

196. Proposal for a Directive of the European Parliament and of the Council on the Criminal-Law Protection of the Community's Financial Interests, COM (2001) 272 (issued May 23, 2001), arts. 3, 4 and 6.

197. Id. explanatory memorandum, II 1.

198. Id. art. 9.

199. Id. preamble, II 11.

200. "Member States shall take the necessary measures to transpose the provisions of this Chapter [defining offenses] into their national criminal law in such a way that the conduct referred to therein constitutes criminal offences." Id. art. 7. However, whereas article 8 of the proposed directive, id., requires that responsible individuals (e.g., corporate officers) should be criminally liable, article 9 only requires that "bodies corporate" be "held liable," thus leaving room for member states to proceed administratively or civilly against corporations.

201. Id. art. 11.

202. Id. art. 9.3. 


\section{d. Proposals related to Corporate Accounting Fraud}

On the heels of the Parmalat accounting scandal, the Commission issued a proposal for a directive requiring member states to adopt EU-wide standards for public company audits. ${ }^{203}$ This directive included a recommendation that member states adopt "dissuasive civil, administrative or criminal penalties" against auditors and audit firms in addition to civil sanctions in cases in which statutorily required audits failed to comply with the proposed EU-wide standards. ${ }^{204}$ One proposed sanction would withdraw "the approval of statutory auditors and of audit firms," ${ }^{205}$ which would be the death knell of a public company audit firm. Interestingly, however, the Commission's overall approach to the recent corporate fraud scandals in Europe has not focused on the use of criminal sanctions. $^{206}$ Similarly, France, Germany, and Italy have

203. Proposal for a Directive of the European Parliament and of the Council on Statutory Audit of Annual Accounts and Consolidated Accounts, issued March 16, 2004, COM (2004) 177, available at http://www.europa.eu.int/eur-lex.

204. Id. art. 30, II 2.

205. Id. art. 30, II 3.

206. Partly in response to this wave of corporate fraud (and also as a result of the EU's policy to harmonize corporate governance in public companies among member states to promote more efficient capital markets), in May 2003, the Commission recommended that member states adopt new rules requiring increased financial transparency, greater shareholder rights, and more defined criteria for director remuneration and responsibilities. See Communication from the Commission to the Council and the European Parliament of May 21, 2003, "Modernising Company Law and Enhancing corporate Governance in the European Union-A Plan to Move Forward," COM (2003) 284. However, the Commission did not propose additional criminal liability on directors, officers and auditors responsible for public company accounting fraud. Here, the Commission declined to follow the policies of Sarbanes-Oxley, enacted less than a year earlier by the United States Congress. See id.; see also Frits Bolkestein, member of the EU Commission's group on the Internal Market, Address to the European Policy Forum London, (June 13, 2003), available in LEXIS at 2003 RAPID June 13, 2003. The Commission's recommendations reflected its view that the wave of scandals indicated a need for fundamental corporate governance reform rather than a criminal law response. 
made civil rather than criminal law the centerpiece of their responses to the recent corporate fraud scandals. ${ }^{207}$

\section{THE IMPLICATIONS OF THE EUROPEAN EXPERIENCE}

As the preceding discussion demonstrates, there are several identifiable trends in Western Europe regarding the imposition of criminal liability on corporations. There has been a general movement toward the imposition of corporate criminal liability, with the use of respondeat superior liability in addition to other liability standards that focus on managerial or organizational fault. The new corporate criminal liability is intended to complement, not replace, the liability of individual actors. Europe increasingly views corporate criminal liability as a needed deterrent and as a mechanism for condemning certain

207. In July 2003, the French legislature adopted legislation requiring greater transparency in financial statements and stricter auditing standards. The legislation also required more disclosure of director stock holdings in the corporation. Luca Enriques, Bad Apples, Bad Oranges: A Comment from Old Europe on Post-Enron Corporate Governance Reforms, 38 Wake Forest L. Rev. 911, 919 (2003). This legislation emulated much of Sarbanes-Oxley's financial reporting disclosure requirements. Id. The legislation also introduced criminal liability on non-traditional securities brokerage firms involved in certain public market investment activities in violation of the new requirements, and predicated such liability on article 121-2 of the new French penal code. Traditional investment banks, such as Crédit Agricole S.A., and investment firms associated with the French bourse remain subject to strict regulations imposed elsewhere in French law on such firms. Art. 44 of the Projet de loi de securite financiere (adopted by the French Senate Mar. 20, 2003), available at http:/www.senat.fr/leg/tas02-092.html.

The German government has proposed legislation emulating SarbanesOxley's disclosure and auditing requirements. The proposed legislation would also make it easier for shareholders to bring actions for damages against individuals responsible for securities fraud. Enriques, supra, at 920-21. A government commission is even exploring more fundamental reforms to the structure of the German corporate board. Id.

Italy also adopted new reforms aimed at curbing self-dealing by directors that were due to come into effect in January 2004. Enriques, supra, at 924-25. However, Italy still has not completely reversed the "de-criminalization" of accounting and securities fraud that occurred in 2001, when the government passed legislation that made the prosecution of corporate officers for fraudulent accounting much more difficult by imposing a higher burden of proof on prosecutors and shortening the statute of limitations. Id. at 922. 
corporate conduct and reinforcing societal norms. Finally, the use of criminal sanctions other than traditional monetary fines, while still not widespread, is now available to courts in at least one European country.

The general movement toward imposing criminal liability began in the 1970s with legislation addressing a few offenses (particularly offenses relating to the economic markets and consumer protection ${ }^{208}$ ) and has now led to the adoption of comprehensive schemes for the imposition of criminal liability on corporations in Denmark, Finland, France, the Netherlands, and Switzerland. ${ }^{209}$ The use of corporate criminal liability was endorsed by the Council of Europe, which recommended in 1988 that member states adopt such liability comprehensively, ${ }^{210}$ and subsequently forwarded specific proposals addressing the criminal liability of corporations for environmental offenses and offenses involving fraud in government contracts. ${ }^{211}$ The European Union has made similar proposals of its own. ${ }^{212}$

A few European countries have bucked the trend, choosing not to adopt corporate criminal liability, and instead employ administrative sanctions. ${ }^{213}$ In Germany these sanctions are regarded as quasi-criminal. ${ }^{214}$ It is questionable whether the hold-outs will continue to rely exclusively on civil or quasi-criminal sanctions. Legal commentators and prosecutors in these countries, especially Germany and Italy, have argued that

208. See supra notes $75,84,89,117,180-186$ and accompanying text (noting original use of criminal or quasi criminal sanctions for economic crimes in France, Italy, Spain, the Netherlands, and the EU). Portugal also imposed vicarious liability on corporations for certain environmental and economic crimes. See supra note 74 .

209. See supra notes 89-119 and accompanying text.

210. See supra text accompanying notes 161-65.

211. See supra text accompanying notes 168-79. The European Union arguably began the modern discussion of corporate liability in Europe when the original EU body imposed civil sanctions on business enterprises for anti-competition abuses in the 1960s. See supra notes 181, 185-86 (noting debate regarding penal nature of of EU's anti-competition fines).

212. See supra text accompanying notes 187-202.

213. See supra note 75 and notes 141-44 and accompanying text (noting that Germany, Italy, and Spain continue to use administrative sanctions).

214. See supra notes $142-44$ and accompanying text. 
administrative sanctions are less effective than criminal liability because they do not provide sufficient deterrence and do not inflict moral condemnation on the corporate offenders. $^{215}$ Moreover, at least in Germany, individual criminal liability is provided for the commission of offenses on behalf of the corporation, but it has not been effective at controlling criminal conduct by corporations. ${ }^{216}$

The second trend among those Western European countries adopting comprehensive liability schemes is the attempt to define a standard of fault that integrates respondeat superior liability with theories of corporate organizational fault. The Netherlands, Denmark, and subsequently Finland have opted to impose respondeat superior liability as well as liability based on organizational or management failures. ${ }^{217}$ Switzerland has recently adopted respondeat superior liability for serious offenses that is qualified by requiring an additional showing that the corporation has not taken reasonable measures to prevent the offense. ${ }^{218}$ This qualification is also seen in the Council of Europe's 1988 proposal. $^{219}$ France remains an exception to the trend, using a limited form of respondeat superior liability, although in the case of negligence-based offenses, the courts are relaxing that standard. ${ }^{220}$

215. See supra notes $147-51$ and accompanying text.

216. See supra notes $146-48$ and accompanying text.

217. See supra text accompanying notes 92-93 (the Netherlands), notes 100-105 (Denmark), and notes 107 (Finland).

218. See supra notes 112-114 and accompanying text.

219. See supra text accompanying note 164 .

220. French law does not automatically impute criminal liability to a corporation based on the conduct of its lower-level employees, but requires a finding of individual criminal liability by senior management or delegated corporate representatives, except in the case of negligence offenses, where the law may impute liability to a corporation even when a senior officer is not personally liable for the offense. This approach recognizes that it may be unfair to impose a criminal judgment on a corporation for the acts of any lower-level "rogue" employee. Coffee, supra note 70, at 23. As discussed in the preceding section, French law is very much in flux, as courts and scholars recognize that the extremely strict interpretation of article 121-2 originally adopted by the Court of Cassation does not appear to be practical in the case of most corporate offenses requiring intentional fault, and is in tension with negligence-based liability 
The third noticeable trend concerns the maintenance of liability of natural persons: the states that have chosen to adopt comprehensive corporate criminal liability have not displaced the liability of natural persons for offenses they commit on behalf of the corporation. ${ }^{221}$ Similarly, various proposals of the Council of Europe and the European Union for corporate criminal liability state that individual liability on culpable managers should remain. ${ }^{222}$ Thus, the introduction of criminal responsibility on corporations is seen as serving practical and moral purposes that are distinct from those served by the imposition of criminal responsibility on individuals acting on a corporation's behalf.

Finally, and relatedly, the scholarly commentary urging the adoption of corporate criminal liability has consistently reflected two purposes that scholars believe can only be served by the criminal law. The first is the infliction of moral condemnation on the corporation itself when it commits an illegal act. Such condemnation reinforces important social norms flouted by the corporation. Some scholars have, accordingly, argued that the corporation represents a set of distinct interests, or has its own personality, and is therefore the appropriate subject of criminal stigma. ${ }^{223}$

imposed on corporations through recent modification of article 121-3. See supra notes 127-35 and accompanying text.

221. This is the case in France and the Netherlands, see supra text accompanying notes 94, 121-22, and appears to be the case in Denmark, see supra text accompanying notes 100-105 (Danish law does not appear to exlude individual liability when a corporation is liable) and Switzerland, although, as noted, the new Swiss provision for corporate criminal liability may deflect liability away from the corporation and back to the individual. See supra notes 108-114 and accompanying text. Belgium, however, has not followed this trend. See supra note 74 .

222. See supra text accompanying note 165 (Council's 1988 proposal), note 170 (Council convention on environmental crimes), note 178 (Council convention on corruption), note 192 (EU Framework Decision on environmental offenses), and note 202 (proposed EU directive on corruption).

223. See supra note 75 and notes 80, 83, and accompanying text (noting comments of Italian and French scholars on distinctive harm created by corporate offenses). 
The second of these purposes is an effective response to the widespread social harm caused by the illegal activities of increasingly economically dominant corporations. Several European commentators have remarked that neither administrative corporate liability nor individual criminal liability on corporate management has succeeded in deterring recidivist corporate misconduct, and that more punitive sanctions against corporate offenders are required. ${ }^{24}$ Proponents of such sanctions have succeeded in having them adopted in France. These sanctions include measures designed to restrict management's conduct of the corporation's business and have been characterized as a form of corporate "imprisonment." 225 Although nonmonetary sanctions, such as revocation of licenses, were already available in countries such as Germany for administrative law violations, ${ }^{226}$ the new sanctions appear to provide more muscular deterrence against corporate misconduct.

What do the European developments tell us about the arguments reviewed in section I? At the most general level, the widespread adoption and expansion of corporate criminal liability in Europe suggests a widely shared perception that corporate criminal liability serves a valuable function in modern western democracies. The European experience also provides a lens through which to reassess the specific critiques of subjecting corporations to the criminal law. In considering these developments, we return to the major arguments we identified in section I.

\section{A. The European Experience and the Retributive Critique}

The retributive argument we reviewed in section I asserts that the function of criminal law is to impose blame, and shame, on individuals as a means of responding to the moral wrong inflicted by their conduct. ${ }^{227}$ According

224. See supra notes $146-48$ and accompanying text.

225. See supra note 140 .

226. See supra notes $143-44$ and accompanying text.

227. See supra text accompanying notes 39-41. 
to this line of reasoning, the criminal law cannot be extended to corporations without losing its moral foundation, and hence its moral force. Twenty-five years ago, most European nations shared the traditional notion that criminal sanctions were, by their nature, appropriate only for natural persons, ${ }^{228}$ and this view still holds sway in the few European nations that have not extended criminal liability to corporations. In Italy, for example, the constitution provides that criminal responsibility "is personal," ${ }^{229}$ and in Germany opposition to criminal liability is predicated, at least in part, on the principle of personal guilt and blameworthiness. ${ }^{230}$

But, in the main, this jurisprudential concern has not carried the day in Western Europe. As detailed in section II, the clear trend is to extend criminal liability to corporations, and the recommendations of the Council of Europe and the European Union are likely to reinforce the trend. Moreover, the European trend also shows an attempt by legal scholars to un-moor corporate criminal liability from the classical notions of individual fault that are central to the retributive argument. In Germany, for example, scholars have argued for a standard of corporate criminal liability based on a theory of organizational fault ${ }^{231}$ and some French scholars have expressed the view that France's limited respondeat superior liability does not reflect the realities of the interaction between a corporation's management and its employees. ${ }^{232}$

The developments in Europe reflect a growing recognition of the economic power wielded by corporations as well as the distinctive threats posed by that power, and a sense that criminal liability should be available to

228. See supra note 72. But see supra note 70 (noting that the U.K. adopted a limited form of criminal responsibility based upon respondeat superior in the 1950s), note 71 (Denmark had limited liability since 1926) and notes 89-90 and accompanying text (the Netherlands had limited corporate liability for economic crimes, and expanded it to comprehensive criminal liability in 1976).

229. See supra note 75 .

230. See supra note 141 and accompanying text.

231. See supra text accompanying notes 152-56.

232. See supra note 129 and accompanying text. 
respond to corporate wrongdoing. ${ }^{233}$ Although the Europeans do not necessarily phrase it in these terms, it seems that the underlying assumption is utilitarian and pragmatic: the notion that society needs additional protection from corporate wrongdoing than has been provided by reliance on administrative or civil law. One commentary on the Danish criminal code makes this point explicit:

The justification for making legal persons liable for punishment is found in practical needs, including above all a desire to be able to sanction anonymous faults and to be able to adjust the level of a fine to the actual or assumed profit of a business (and not merely the financial situation of the perpetrator). This is particularly called for where the actual perpetrator is a person in an inferior position receiving only a minor salary who has acted in the interest of the business. ${ }^{234}$

There is, however, also some discussion of the need to hold corporations responsible, and to express society's denunciation of certain forms of corporate misconduct. The expressive function and social meaning of the new European criminal laws is discussed below. ${ }^{235}$

\section{B. The European Experience and the Economic Efficiency Critique}

As described more fully in section I, the law and economics efficiency critique is utilitarian in its orientation, seeking to weigh the costs and benefits of corporate criminal liability as opposed to corporate civil liability or criminal liability for individuals. One facet of this

233. See supra text accompanying notes 83-87.

234. Langsted et al, supra note 98 , at 48 , II 81 . The authors also comment that "Danish legislation as well as jurisprudence of penal law have traditionally been highly pragmatic, and philosophical considerations regarding guilt depending upon human actions and similar points of view have never gained much ground." Id. at $47-48$, II 81.

235. See infra text accompanying notes $281-84$. 
argument is the claim that criminal liability is inefficient because it overdeters, causing precautionary behavior that is not socially beneficial. ${ }^{236}$ Another facet is the claim that the heightened procedural protections and reputational damages cause unnecessary and sometimes perverse social costs. ${ }^{237}$ Because the sanctions available and the procedures followed in each country in civil and criminal proceedings vary a good deal, ${ }^{238}$ the exact balance of costs and benefits varies from country to country as well. Accordingly, no close comparisons can be made between the utilitarian balance in the U.S. and that in Europe.

There is, however, one distinction between the U.S. and European systems that may have predisposed the latter to turn to criminal sanctions as a mechanism to control corporate misconduct. In comparison to the U.S., European states have traditionally relied more on administrative regulation ${ }^{239}$ and less on civil litigation to

236. See supra text accompanying notes $42-43$.

237. See supra text accompanying notes $45-51$.

238. For a general discussion of criminal procedure in Western European countries, see Craig M. Bradley, Criminal Procedure, A Worldwide Study (1999). Some of the procedures in the U.S. and Western Europe are similar. For example, most countries have a heightened standard of proof in criminal cases, although each may use different terminology. In France, jurors must be thoroughly convinced of guilt to convict. Id. at 173. England, like the U.S., uses beyond a reasonable doubt. Id. at 122. Jurors in Germany decide guilt based on factors which leave no room for reasonable doubt. Thomas V. Mulrine, Note, Reasonable Doubt: How in the World Is It Defined?, 12 Am. U.J. Int'l L. \& Pol'y 195, 220 (1997). The Italian Constitution requires a definitive conviction (Id. at 222), although recently the Italian Supreme Court has applied a standard that is comparable to the reasonable doubt standard. See also Michele Taruffo, Rethinking the Standards of Proof, 51 Am. J. Comp. L. 659 (2003) (arguing that while there is some overlap in the criminal and civil standards of proof in civil countries, generally, civil courts do not use as rigorous a standard as criminal courts). But see Kevin M. Clermont \& Emily Sherwin, A Comparative View of Standards of Proof, 50 Am. J. Comp. L. 243 (2002) (arguing that most civil law countries use a heightened standard of proof for both civil and criminal trials).

239. In the last century, Western European countries chose to regulate corporate conduct primarily through administrative liability. See Leigh, supra note 70, at 1522 (noting the availability of a "wide measure of administrative liability" in European countries, including those that do not have criminal liability); Beth Stephens, The Amorality of Profit: Transnational Corporations and Human Rights, 20 Berkeley J. Int'l L. 45, 64 (2002) (noting that after the French Revolution, corporate criminal liability "fell into disfavor," in part because 
control and sanction corporate conduct in areas such as protection of consumers, ${ }^{240}$ the environment, ${ }^{241}$ and business competition. ${ }^{242}$ The civil remedies available in many European nations are underdeveloped as compared to those in the U.S. In some contexts, private plaintiffs may sue for injunctive relief, but not compensatory damages. ${ }^{243}$ In other contexts, compensatory damages are available, but not punitive damages. ${ }^{244}$ Thus the addition of corporate criminal liability may reflect, in part, the Europeans'

"corporate-style institutions were disbanded").

240. France and Italy, for example, enforce consumer protection laws through "strong, detailed regulation, largely sanctioned through criminal or administrative law measures.” Frauke Henning-Bodewig, Unfair Competition and Misleading Advertising: The Approach to Regulation in the Continental EC States (Including the EC Directive on Misleading Advertising), 54 Antitrust L. J. 551, 555 (1985).

241. Throughout Western Europe, environmental laws are enforced through administrative regulations and sanctions, though with varying degrees of deterrent effectiveness. See generally Michael Faure \& Günter Heine, Environmental Criminal Law in the European Union (Max Planck Institute 2000) (canvassing member state environmental criminal law regimes).

242. In the area of competition laws, "both the German laws and the competition rules of the European Economic Community provide for heavy penalties." Leigh, supra note 70, at 1523.

243. Germany, Austria, Italy, Spain and Switzerland, for example, have granted consumer associations standing to seek injunctions without damages against businesses for violations of consumer law, such as misleading advertising. Gerhard Walter, Mass Tort Litigation in Germany and Switzerland, 11 Duke J. Comp. \& Int'l L. 369, 375 (2001); Harald Koch, Non-Class Group Litigation Under EU and German Law, 11 Duke J. Comp. \& Int'l L. 355, 359-60 (2001). Some states, such as Norway and Sweden, have a "Consumer Ombudsman" that may seek to enjoin business practices. Koch, supra, at 362 .

244. Although some countries have adopted procedures that allow the award of compensatory damages to groups of injured plaintiff groups in tort cases, European systems have not generally authorized punitive damages. See Koch, supra note 243, at 360-61 (noting difference between public interest style suits and claimant group suit in tort cases). There are already some indications, however, that European nations may move further to expand civil liability. Courts in France and Greece have begun to award punitive damages in civil suits brought by associations. Id. at 360. Increasingly, the European Union is also recommending that member states adopt private plaintiff civil actions against corporations in various fields, such as securities law. See, e.g., COM 2003/284, supra note 206, II 3.1 .3 (proposing shareholder right to seek official investigation into company's affairs); COM 2004/177, supra note 203, art. 30 (encouraging member states to provide "effective, proportionate and dissuasive civil, administrative or criminal penalties" against audit firms). 
greater reliance on the state, rather than private litigants, to respond to corporate misconduct. In effect, criminal liability has given the state the option of seeking more serious sanctions to respond to greater societal harm.

In addition, several other points emerge from the European experience. First, some aspects of the new legislation seem to take account of efficiency considerations, broadly defined, since they impose criminal liability on the corporation where other options are limited or unavailable. Some of the corporate criminal statutes were designed to plug a gap in the existing legal framework, as in the case where no responsible individual can be identified. ${ }^{245}$ Similarly, German scholars and prosecutors are advocating corporate criminal liability on the ground that corporations are able to structure their transactions to avoid most individual liability, and further dilute the deterrent effect of the current laws by indemnifying the few individuals who are prosecuted. ${ }^{246}$ More generally, Europe clearly intends corporate criminal liability to serve as an additional tool, not a substitute for other-possibly more effective-sanctions against corporations themselves or individuals. ${ }^{247}$

On the other hand, as far as we can tell, the European dialogue concerning the creation of corporate criminal liability shows little sign of the influence of law and economics considerations, such as the relative efficiency of

245. See, e.g, supra text accompanying note 90 (noting that Dutch law has dispensed with predicating corporate liability on conduct of a natural person), notes 103 and 107 (noting Danish and Finnish law, respectively, do not require identifying individual wrongdoer who performed the corporate offense), and notes 108-114 (noting that under Swiss law, corporation liable for some offenses where individual wrongdoer is not identified, and always liable for certain serious offenses regardless of individual liability).

246. See supra notes 147-50 and accompanying text.

247. See supra text accompanying notes 165, 170, 178, 192, and 202 (noting that Council of Europe and European Union initiatives do not displace individual liability and also contemplate civil and administrative remedies). This does not guarantee, however, that in practice the availability of corporate liability will not tend to shield individuals. See Khanna, supra note 54, at 17-18, 21-23, 8 n.40 (arguing that in the U.S., corporate interests favor corporate liablity and lobby against increased enforcement of individual liability, although formally there is no barrier to individual liability). 
different legal options, or concerns about perverse incentives or the potential for under- or overdeterrence. The push to adopt criminal sanctions reflects a consensus that new and stronger tools are needed to respond to the potential for widespread damage from corporate misconduct, ${ }^{248}$ but there is relatively little systematic discussion of the distinctive costs and benefits to enacting or enlarging corporate criminal liability. Although some opponents of corporate criminal liability in France expressed concern that criminal sanctions would be redundant of existing administrative fines and would fall heavily on shareholders, employees, and creditors, ${ }^{249}$ those arguments do not seem to have received the same thorough and critical discussion given to doctrinal arguments in the U.S. against corporate criminal liability. This lack of emphasis might reflect the conclusion that criminal sanctions are efficient, or that efficiency concerns are not an appropriate basis for assessing the propriety of criminal sanctions, but it seems equally plausible that European scholars have not employed law and economics scholarship to analyze these questions..$^{250}$

\footnotetext{
248. This view is reflected on the national level, see, e.g., supra note 75 (Paliero, arguing for corporate criminal law in Italy, noted that the "more invasive activities" of corporations cannot be controlled without punitive sanctions), and at the broader transnational level, see, e.g., supra text accompanying notes 161-62 (Council of Europe endorsed criminal liability because activities beneficial to corporations were causing considerable damage for which responsible officials could not be identified), and at the level of the EU, see supra text accompanying notes 196-97 (Commission finding that injury to EU's financial interests made tougher sanctions for bribery of European Union funds and money laundering urgent).

249. See supra note 88 and accompanying text.

250. It appears that law and economics scholarship plays a less prominent role in Europe than in the United States. For example, there are eight law and economics journals in the U.S., and only one in Europe. Richard A. Posner, Law and Economics in Common-Law, Civil-Law, and Developing Nations, 17 Ratio Juris. 66, 66 n.1 (2004). In describing the wide influence law and economics scholarship has in the U.S. and arguing that it can play a similar role in civil law countries, Judge Posner seems to imply that it has not yet achieved this prominence outside the U.S. See id. at 66-67. In general, it appears that to date European law and economics has been more concerned with private law than with public law. See, e.g., Ugo Mattei, Comparative Law and Economics (1997) (discussing, inter alia, property, private trusts, and torts).
} 
The European move towards corporate criminal liability also reflects, among some proponents, a sense that criminal sanctions express and reinforce certain social norms. The impact of expressing and reinforcing social norms can, of course, be factored in a utilitarian calculus, ${ }^{251}$ but we did not observe European commentators discussing the normative value of criminal sanctions against corporations in these terms. The expressive and norm building functions of criminal law, as argued by European commentators, are discussed below in subsection D. ${ }^{252}$

\section{The European Experience and the Public Choice Critique}

As noted in section II, a public choice perspective suggests that corporate criminal liability may be enacted not because it is an effective and important response to corporate wrongdoing, but rather because it is relatively inefficient or ineffective, and hence the least objectionable to politically powerful corporate interests. ${ }^{253}$ Corporate liability is thus dangerous in both the legislative and prosecutorial contexts, because it will tend to substitute for more effective sanctions, leading to underdeterrence of corporate wrongdoing. Extending this analysis internationally, we might predict that powerful corporate interests in Europe, like those in the U.S., will employ their political influence to steer the system towards corporate criminal liability only when it serves their interests to do so. This bleak picture of the legislative process suggests that it will seldom be the case that one can find desirable models in the statutory laws of any democratic nation (though the common law may produce efficient rules ${ }^{254}$ ).

251. For a forceful statement of this position, see Kahan, supra note 62, at 617; see also supra text accompanying notes $62-63$.

252. See infra text accompanying notes $280-85$.

253. See supra text accompanying notes 54-56. Consistent with this theory, it appears that corporations have raised stronger opposition to criminal liability for corporate agents and to civil liability for entities than to corporate criminal liability. See supra note 56 and accompanying text.

254. Law and economics scholars have traditionally argued that the common 
Although there is certainly some explanatory power in the public choice critique of the U.S. legislative process, this analysis cannot be transferred directly to the experience in Europe. Because the various western democracies have different political traditions and culture, as well as different governmental structures and institutions (including key variations regarding the strength of political parties and the distribution of legal sovereignty), the role of interest groups in each varies. ${ }^{255}$ Even allowing for this variation, it seems clear that the role of interest groups in European politics is not entirely comparable to the role of such groups in U.S. policies. The relative weakness of the party system in the U.S. contributes to the power of U.S. interest groups, which have much more influence in the electoral process than their counterparts in Europe. ${ }^{256}$ There are significant

law evolves toward efficient rules. See generally Richard A. Posner, Economic Analysis of the Law 25-26, 573-75 \& n. 1 (6th ed. 2003); Oona A. Hathaway, Path Dependence in the Law: The Course and Pattern of Legal Change in a Common Law System, 86 Iowa L. Rev. 601, 637-38 (2001). In recent years, however, various challenges to this view have been made. See, e.g., Hathaway, supra, at 638 (observing that path dependence theory suggests that rules such as stare decisis may preclude common law courts from reaching efficient results), and Todd J. Zywicki, The Rise and Fall of Efficiency in the Common Law: A Supply Side Analysis, 97 Nw. U. L. Rev. 1551 (2003) (noting the evolution away from the traditional view of the common law's efficiency because of interest group pressures on litigation, and offering a supply side as well as a demand side account of the pressures that shape common law decision making). For more general evolutionary analyses of law, see E. Donald Elliott, The Evolutionary Tradition in Jurisprudence, 85 Colum. L. Rev. 38 (1985), and Owen D. Jones, Proprioception, Non-Law and Biolegal History, 53 Fla. L. Rev. 831 (2001).

255. Clive S. Thomas, Interest Groups in Western Democracies: Contemporary Characteristics and Future Directions, in First World Interest Groups, A Comparative Perspective 223-24 (Clive S. Thomas ed., 1993) [hereinafter First World Interest Groups]. At least during periods in their history, several of the Western European states have a corporatist structure, with well defined national interest groups and unions that are formally consulted by the government. Clive S. Thomas, The American Interest Group System, Typical Model or Aberration?, in First World Interest Groups, supra, at 41 [hereinafter Typical Model or Aberration]. See Yves Meny, Government and Politics in Western Europe 152 (Janet Lloyd trans., 2d ed. 1993). These "peak associations" organize the other interest groups, and represent them in negotiations or enforce any agreement that would be made; such associations are lacking in the U.S. Clive, Typical Model or Aberration, supra, at 42.

256. Clive, Typical Model or Aberration, supra note 255, at 43. The U.S. PACs 
differences in the relationship between interest groups and government in the U.S. and various European nations, and in the tactics and strategies that interest groups use to influence government. ${ }^{257}$

Moreover, as noted by comparative political science analysts, some of the European nations that have enacted corporate criminal liability have bureaucracies that are more insulated from interest groups, and also have political party systems that are much more powerful than the party system in the United States. In particular, France has a powerful executive, an insulated bureaucracy, and parties that are not likely to be controlled by special interests..$^{258}$ Although business leaders (and representatives of trade) are among the most likely to be consulted, French political leaders with clear policy preferences are generally successful in imposing these views. ${ }^{259}$ In this situation the government may consult the affected groups as a formality, but if interest groups are not consulted or if their positions are not influential, they have little recourse but to protest. ${ }^{260}$ This appears to have been the case with the 1992 adoption of the French provisions creating comprehensive corporate criminal liability. Despite the opposition of the business community, the legislature followed the recommendation of the French law reform commission. ${ }^{261}$ Subsequently, in July 2000, the French

strengthen the relationship between groups and individual elected officials or candidates, decreasing the strength of political parties in the U.S. Id. at 41 . The weak political parties contribute to the "fragmented nature of the American policymaking process." Id.

257. Id. at 49. Several key mechanisms used by interest groups in the U.S., such as paid professional lobbyists, are less prevalent in Europe. Id. at 37, 39. Influencing the election of candidates through PACs, which tend to represent business interests, is virtually unheard of in other western democracies. Id. at 46. PACs tend to be dominated by business interest groups, and tend not to represent the interests of promotional groups, i.e., public interest or single-issue groups promoting a social ideal or cause, such as the ACLU or Mothers Against Drunk Driving. Id. at 41.

258. Frank L. Wilson, France: Group Politics in a Strong State, in First World Interest Groups, supra note 255, at 114-15, 122.

259. Id. at $124-25$.

260. Id. at 125 .

261. In an interview with one of the co-authors, Marie-Christine Monsallier- 
legislature expanded negligence-based corporate criminal liability, placing into question the Court of Cassation's overly narrow reading of the scope of liability under the 1992 law. ${ }^{262}$

Therefore, the development of corporate criminal liability in the various European nations does not seem to have followed the script suggested by the public choice critique. The process varied considerably from country to country in Europe, ${ }^{263}$ and seldom if ever followed the paradigm assumed by the public choice critique-corporate interests urging legislators to adopt criminal liability to avoid more effective sanctions against corporations. It does not appear that recent European legislation was a substitute for other civil or administrative remedies or individual criminal liability. Rather, corporate criminal liability was seen as a necessary adjunct to existing provisions that may or may not have more bite. This is particularly clear in the case of Swiss law, which provides for corporate criminal liability when fault cannot be attributed to an individual within the organization. ${ }^{264}$ Swiss law also provides for corporate criminal liability in the case of a group of offenses that are often facilitated by the corporate form of organization (money laundering, bribery, corruption, organizational crime, and the financing

Saint Mleux observed that in general, French legislative reform commissions tend to be formed exclusively of legislators, though well known legal scholars sometimes have significant access to legislative reform commissions. These legislators receive informal input from both the academic community and other representatives of affected interest groups, although the latter do not play as central a role in the drafting of legislation as they do in the United States. Interview with Marie-Christine Monsallier-Saint Mleux, Docteur en droit, Maitre de conférences à la Faculté de Droit de l'Université de Lille II, in New York, New York (June 6, 2004) (interview notes on file with authors).

262. See supra notes 131-32 and accompanying text.

263. The Netherlands and Denmark, for example, incrementally introduced corporate criminal liability, see supra text accompanying notes 89-99, whereas France took years to debate it before finally introducing it, for the first time, comprehensively. See supra text accompanying notes 116-17.

264. See supra note 109 and accompanying text. Similarly, one basis for criminal liability under Finnish law is the absence of an identified wrongdoer coupled with the corporation's lack of the care and diligence necessary to prevent the offense. See supra text accompanying note 107. 
of terrorism), regardless of whether a wrongdoer has been identified, when the corporation has failed to take reasonable and necessary measures to prevent the offense. ${ }^{265}$ This would suggest that with respect to such offenses, criminal sanctions are viewed as desirable. Further, some nations have addressed the concern that the new provisions not act as a substitute or shield for culpable individuals. The French code provides that a corporation's criminal liability does not shield a natural person who is a perpetrator or accomplice of the same act. ${ }^{26}$ Dutch law allows the prosecution to charge the corporation and/or the responsible corporate official(s). ${ }^{267}$

Similarly, the European experience strays from the public choice critique's script in another way. That critique suggests that criminal liability is usually the result of a scandal that generates public outcry and a demand for a hasty legislative response to corporate wrongdoing. ${ }^{268}$ To the contrary, in several European countries, criminal liability was enacted as a result of a lengthy deliberative process in which legal scholars who supported such liability played a significant role. Europeans held academic congresses to address corporate criminal liability in 1978, 1979, and $1993 .^{269}$ In France, adoption came after more than a decade of debate, as legal scholars and legislators sought new means to hold increasingly powerful economic entities responsible for their conduct within society. ${ }^{270}$ Similarly, in Germany much of the impetus to consider

265. See supra text accompanying notes $112-13$.

266. See supra text accompanying notes 121-22.

267. See supra text accompanying note 94 .

268. See Khanna, supra note 54, at 21-22 (noting that response to corporate accounting scandals was to enact Sarbanes-Oxley, not to repeal recent limitations on scope of civil liability). At the same time, events such as the provision of blood tainted with HIV in France, see supra note 86 and accompanying text, and the nuclear disaster at Chernobyl were also in important ingredient in the debate about the need for additional laws to regulate and sanction corporate wrongdoing. Although Chernobyl involved a government nuclear plant, it was a dramatic example of the catastrophic harm that can occur as a result of an industrial accident.

269. See supra note 76 .

270. See supra text accompanying notes $82-88$ and $115-19$. 
corporate criminal legislation appears to be coming from academics, who have noted that the current system of administrative liability woefully under-deters corporate offenders. ${ }^{271}$

The recent corporate accounting scandals provide an interesting test of this aspect of the public choice analysis, since there has been a genuine public outcry and new laws have and are being adopted in the U.S. and Europe. But in Europe, the result has not been knee-jerk adoption of new criminal laws. Although a few new criminal provisions have been adopted, both the European Union and the individual European states have emphasized civil provisions, particularly stricter standards for accounting and audits, increased financial transparency, greater shareholder rights, and defined criteria for directors' responsibility and remuneration. ${ }^{272}$

Moreover, the European Union's support for certain forms of corporate criminal liability poses an additional challenge to the public choice argument. The European Union has called upon its member states to enact criminal legislation to deal with four particularly pressing problems that characteristically involve corporate activity: environmental crimes, government contract fraud, bribery directed at the use of European Union funds, and money laundering. ${ }^{273}$ These proposals, which emanate from the Commission of the European Union and must be approved by the Council of the European Union, are the result of a quite different political process than the national laws referred to above. The multi-level structure of EU policymaking creates a system that is too complex for one type of interest group, such as business interests, to dominate. ${ }^{274}$ The necessity of influencing multiple branches

271. See supra notes $145-50$ and accompanying text.

272. See supra notes 206-07 and accompanying text.

273. See supra text accompanying notes 187-202. As noted, these are similar to proposals made by the Council of Europe. See supra text accompanying notes 168-80.

274. The European Union has a tripartite structure, involving the Council of Ministers, the European Commission, and the European Parliament, and lobbyists must learn about each, and their interactions. Sam Lowenberg, For 
of government and the diffuse power structure can serve to fragment business interests and "insulate" policymaking from private interests compared to the more direct lobbying process employed in individual states. ${ }^{275}$ Traditional interest groups that had focused on lobbying national governments found this tactic increasingly ineffective as the EU moved toward integration, and each nation state lost conclusive veto power after the implementation of qualified majority voting in the Council of Ministers. ${ }^{276}$ At the level of the EU, new nontraditional qualifications were necessary to gain influence, such as the creation of a "European identity" and the establishment of panEuropean alliances. ${ }^{277}$ Although business interests in the EU are the most organized private interest in civil society, ${ }^{278}$ their task is much more daunting than private interests who can be successful operating at a national level. Lobbying at the European Union has been compared to playing three dimensional chess. ${ }^{279}$

American Businesses, Lobbying the European Union Has Become a Priority, Legal Times, March 8, 1999, at 1. Until the admission of new states in 2004, interest groups had to contend with fifteen different nation-states, each of whom support different policies, social norms, and political goals, and seven different political coalitions, none of whom controls a majority. Id. This translates into a process that requires coalition building and compromise in order to achieve passage of any directive or regulation. Justin Greenwood, Interest Representation in the European Union, 2 (2003).

275. Traditional lobbying techniques used by businesses are unsuccessful at the EU level. The single market adopted in Europe makes bare threats by businesses to leave the market irrelevant; legislators are rarely elected directly by the public so constituent pressure is nonexistent; and large "war chests" do not necessarily gain businesses more influence because wining and dining individual politicians cannot create the political coalitions needed to advance legislation. Lowenberg, supra note 274, at 1 .

276. David Coen, The European Business Interest and the Nation State: Largefirm Lobbying in the European Union and Member States 18 J. Pub. Pol'y, 75, 77 (1998).

277. Id. at 77-78.

278. Greenwood, supra note 274 , at 75 .

279. Id. (quoting Brad Staples, joint managing director of APCO Europe). 
D. The European Experience and the American Defenses of Corporate Criminal Liability

As we have noted, another group of American legal scholars have argued that corporate criminal liability can be justified on several grounds (although there are additional procedural requirements). Such liability plays an important role in expressing and reinforcing important social norms by denouncing violations of those norms. Such liability also serves a variety of pragmatic considerations. ${ }^{280}$ We now turn to examining how the European experience bears on these arguments in support of corporate criminal liability.

\section{The Role of Moral Sanction}

The developments in Europe provide some support for the notion that criminal law plays a role in reinforcing important norms of corporate conduct and shaming or stigmatizing irresponsible corporate actors. In the debates leading up to the adoption of the laws in question, some European theorists justified criminal liability on the ground that only corporate sanctions can express society's moral opprobrium. ${ }^{281}$ Commentators expressed the view that in modern economies corporate wrongdoing represented a significant and distinctive form of delinquency to which the law should respond. In France, commentators expressed the view that corporations should be held responsible, using the language of guilt and blame. ${ }^{282}$ Consistent with that notion, one of the sanctions authorized by French law is the posting of notices in the media. ${ }^{283}$ Similarly, a commentator referred to the Dutch corporate criminal sanctions as designed to inflict "grief" and focus on "moral intention," in contrast to the

280. See supra text accompanying notes 63-69.

281. See, e.g., supra note 75 (noting comments of Paliero and Militello) and note 80 and accompanying text (Tiedemann discussing academic perspective).

282. See supra notes 83 and 85 and accompanying text.

283. See supra text accompanying note 140 . 
administrative regime's focus on "reparation." 284 But as we observed in discussing retribution, ${ }^{285}$ this theme may have been less important to European proponents of corporate criminal liability than pragmatic considerations.

2. The Adoption of Standards of Liability that Integrate Respondeat Superior with Theories of Organizational Failure

Some of the European nations whose corporate liability schemes we discussed in part II are attempting to define a standard for corporate criminal liability that will encourage responsible corporate behavior and sanction conduct that falls seriously short of that standard. The Netherlands, Denmark, Finland, and, most recently, Switzerland have adopted standards of liability that combine respondeat superior liability with theories of management or organizational failure. France stands alone in adopting a far more limited standard of corporate liability. French law permits liability to be imputed to a corporation for offenses requiring intentional fault only where it can be shown that a high level officer or agent is also personally criminally responsible for the offense. ${ }^{286}$ For negligence-based offenses, French law appears to be

284. See supra note 89 .

285. See supra text accompanying notes 233-35.

286. French law is thus even more limited in the application of respondeat superior liability to the corporation than the Model Penal Code's formulation of respondeat superior liability for offenses that have not been specifically imposed on corporations by the legislature. See Model Penal Code $\$ 2.07(1)(c)$ (Proposed Official Draft 1962) ("A corporation may be convicted of the commission of an offense if ... the commission of the offenses was authorized, requested, commanded, performed or recklessly tolerated by the board of directors or by $a$ high managerial agent acting in behalf of the corporation within the scope of his office or employment.") (emphasis added). Moreover, unlike the Model Penal Code, French law only permits a corporation to be responsible for offenses that are specifically identified as corporate offenses by the legislature. Furthermore, for offenses specifically identified by the legislature, the Model Penal Code relaxes the standard of respondeat superior liability. See Model Penal Code $\$ 2.01$ (1)(a) (Proposed Official Draft 1962). As discussed supra note 129 and 132, this narrow interpretation of French corporate liability is under review by French scholars urging its relaxation. 
adopting a more relaxed standard of respondeat superior liability.

Although the use of respondeat superior liability was probably borrowed from the American model of corporate criminal liability, those countries that do use it have not chosen to displace it with another standard of liability when their legislatures enacted comprehensive schemes, but instead have supplemented it. Thus, at least implicitly, the continued use of respondeat superior liability reflects a general consensus among legislators and perhaps even scholars that it is an appropriate standard for corporate liability.

At the same time, these countries, with the exception of France, have included another component to corporate criminal liability-an examination of management's role in supervising and organizing the corporation. The focus on corporate organization has been termed the "deficient" or "defective" organizational model. This approach permits responsibility to be imputed to a corporation when the corporation is unable to show that management has been reasonably diligent in the conduct of its affairs or when the organization of the corporation is shown to be "deficient" or "defective" such that a responsible person cannot be identified. ${ }^{287}$ The managerial/organizational approach prevents a corporation from shielding itself from liability where it is clear an offense has occurred but a responsible individual cannot be identified, and thus reaches corporate misconduct that vicarious liability may fail to capture. ${ }^{288}$

287. The concept of "organizational deficiency" is still being developed by legal scholars and the courts. See supra note 114 (noting introduction of concept into Swiss law in 2003) and supra text accompanying notes 153-54 (proposals of German scholars for standard of liability). Moreover, the concept of organizational deficiency overlaps with management's reasonable oversight and conduct of the corporation, in that management is necessarily responsible for corporate chains of command, the organization of different departments within the corporation, and channels of communication.

288. This discussion is relevant in cases where the offense requires proof of at least negligent conduct by the corporation, but is obviously inapplicable where the law creates strict liability. 
Although these countries combine respondeat superior liability with the management/organizational standard, they do so in different ways. The approach of the Netherlands, Denmark, and Finland seemingly permits courts to liberally apply all these theories of liability as may suit the facts of the offense. ${ }^{289}$ The Swiss approach to serious offenses qualifies the use of respondeat superior liability with an examination of organizational deficiencies and the quality of management's oversight. ${ }^{290}$ If management can show that it took all necessary measures to prevent the offense, the corporation may avoid vicarious liability for the act of an employee. As noted, French law, as interpreted by the judiciary, does not adequately account for organizational deficiencies or high level managerial delinquency, but French scholars have urged a more expansive interpretation of the law. ${ }^{291}$

It is unclear how these different standards of corporate criminal liability will play themselves out in the actual

289. See supra text accompanying notes 91-107.

290. See supra text accompanying notes 113-14. Similarly, the Council of Europe's 1988 proposal permits a corporation to avoid vicarious liability when management is not "implicated in the offense and has taken all the necessary steps to prevent its commission." See Council Recommendation No. R (88) 18, supra note 161, II 2 and II 4 . As noted, in the case of non-serious offenses, the Swiss statute actually shields a corporation from liability for the conduct of an employee, unless the corporation's organization prevents the identification of a responsible employee. See supra note 109 and accompanying text.

The Swiss approach to serious offenses and the Council of Europe's 1988 proposal are similar to the Model Penal Code's limitation of respondeat superior liability based on the conduct of lower level employees, in cases in which "the [corporate] defendant proves by a preponderance of evidence that the high managerial agent having supervisory responsibility over the subject matter of the offense employed due diligence to prevent its commission." See Model Penal Code $\S 2.07(5)$ (Proposed Official Draft 1962).

Although the Council of Europe's 1988 proposal for general corporate criminal liability was not adopted, it appears to have influenced the scholarly debate in member states. See, e.g, Möhrenschlager, supra note 74, at 94-95 (discussing the Council's 1988 Recommendation as a "milestone"). Moreover, both the Council of Europe and the EU's policymakers continue to urge member states to adopt a management-focused approach to corporate criminal liability, as evident in their recommendations urging criminal liability for government fraud, corruption in government contracting, and money laundering. See supra text accompanying notes 168-202.

291. See supra notes $129-30$ and accompanying text. 
prosecution of cases. On the one hand, the emphasis on corporate organization and managerial oversight permits prosecutors to hold corporations liable for offenses requiring a demonstration of some degree of mens rea by the corporation even when a responsible individual cannot be identified. At the same time, it prevents management from deflecting liability onto lower level employees by structuring the corporation so as to insulate management. On the other hand, if a corporation is able to show that its management took reasonably necessary steps to guard against the commission of the offense, it may be more difficult for European prosecutors to prove liability than their U.S. counterparts, even when the law provides for vicarious liability. ${ }^{292}$

\section{The Use of Alternative Non-Monetary Sanctions}

Of equal significance to European proponents of corporate criminal liability is the idea that new criminal sanctions are more effective tools in attempting to manage the potential for widespread harm as a result of the enormous power wielded by corporations. ${ }^{293}$ Most European countries continue to rely on monetary sanctions. ${ }^{294}$ However, alternative sanctions are available

292. U.S. federal prosecutors are encouraged to exploit the full scope of respondeat superior liability in pursuing criminal charges against corporations. The fact that a corporation's management has previously instituted a compliance program or is being cooperative with investigators should not presumptively weigh against an initial charging decision. Prosecutors should consider such factors during the plea and sentencing stage. See Memorandum of Larry D. Thompson, Deputy Attorney General, Principles of Federal Prosecution of Business Organizations, United States Department of Justice, January 20, 2003. Another factor that must be considered in assessing the comparative success of prosecutions of corporations (which is beyond the scope of this article) is the extent to which national legislatures impose strict-liability offenses on corporations.

293. See supra note 75 (Militello discussing need to integrate corporate crime into notion of criminal law to address corporate crime); supra text accompanying notes 85-86 (French commentators discussing harm from corporate conduct); supra note 151 (noting inadequacy of sanctions in Germany).

294. Switzerland's 2003 law provides only for the use of monetary sanctions. See Wittmer, supra note 109, $\S 4(\mathrm{e})$. German law, however, provides for limited 
in France and also have support from the EU, the Council of Europe, and some German proponents of corporate criminal liability. Both the French statute and the Council of Europe's 1988 proposal provide for non-monetary sanctions that can control a corporation's prospective behavior in ways that civil monetary fines cannot. Some of these sanctions seek to supervise or replace management that was at the helm when the offense was conducted. The French code permits a court to supervise management's conduct of the corporation, such as its ability to enter into major contracts on the corporation's behalf, ${ }^{295}$ and the Council of Europe's 1988 proposal goes a step further, providing for the appointment of a replacement management group. ${ }^{296}$ Another type of sanction restricts the corporation's business operations. Thus, a corporation may be prohibited from advertising its goods and services, prohibited from seeking to raise financing through the issuance of debt, limited in its ability to issue checks and lines of credit, and prohibited from receiving certain government benefits and licenses. ${ }^{297}$ A third type of sanction is designed to shame the corporation-such as the announcement of a corporation's conviction in the media or its listing on a registry of corporate offenders. ${ }^{298}$ A final type of sanction is the equivalent of a corporate death penalty: both the French statute and the Council of Europe's 1988 proposal provide for the dissolution of a corporation in extreme cases of criminal delinquency. ${ }^{299}$ It remains to be seen whether French courts will utilize these sanctions with regularity or simply apply monetary fines, and whether other European countries will adopt some of the more aggressive non-monetary sanctions. ${ }^{300}$

\footnotetext{
non-monetary sanctions against corporations found in violation of civil and administrative regulations. See supra note 143 .

295. See supra note 140 and accompanying text.

296. See supra note 166 and accompanying text.

297. See supra notes 140,166 , and accompanying text.

298. See supra notes 140,166 , and accompanying text.

299. See supra notes 140,166 , and accompanying text.

300. In the United States, monetary fines have been supplemented with corporate monitoring, giving prosecutors and courts some input into corporate
} 


\section{CONCLUSION}

The developments in Europe provide an interesting contrast to the American experience, but it is too soon to draw any clear lessons beyond the most basic point that corporate criminal liability may play a more useful role in both Europe and the United States than its U.S. detractors believe. European nations increasingly see corporate criminal liability as an important option for controlling and responding to corporate misconduct, though Germany and Italy are important exceptions: those countries employ quasi-criminal administrative sanctions that appear to satisfy the EU and Council of Europe's recommendations for corporate liability.

There is no European consensus on the standard for corporate liability. Although many European countries base criminal liability on respondeat superior, it is often complemented with liability based on organizational or management failures. We cannot predict which theory or theories of liability will predominate, but it seems likely that the role of management in supervising the corporation's affairs and in organizing the corporation will be an important element of European corporate criminal liability. Significantly, German and French scholars have emphasized an organizational or management-role inquiry into criminal responsibility rather than focusing solely on respondeat superior liability. Moreover, to the extent that

remedial measures. See, e.g., U.S.S.G. § 8D1.4 (November 1, 2003). As a result of the passage of the Sarbanes-Oxley Act, the 2004 amendments to the federal sentencing guidelines emphasize the need to structure internal remedies that promote an "ethos" or corporate ethic of compliance with the law. See, e.g., U.S.S.G. § 8B2.1(b)(2)-(b)(6) (increasing training requirements for corporate compliance programs and requiring greater oversight and enforcement of same). Such remedies can include ethics training for corporate employees. See U.S.S.G. $\S 8 \mathrm{~B} 2.1(\mathrm{~b})(4)$. However, other non-monetary sanctions have not been widely adopted in the United States; they have not been widely discussed by scholars, particularly law and economics scholars, despite some creative proposals for more effective sanctions. See Coffee, supra note 44, at 387, 413-18 (proposing replacing monetary criminal fines with an equity fine, in which the corporation would be required to issue a block of voting stock to a victims trust fund that could transfer the stock without restriction). 
the EU and the Council of Europe's recommendations in this area influence different academic, legislative, and judicial communities within the member states, the message from those European intergovernmental organizations is that the role of management should be an important factor in drafting standards for corporate criminal liability. The European focus on organizational failure as a complement to respondeat superior liability should be broadly consistent with the anticipated combined effect of the post-Sarbanes-Oxley federal sentencing guidelines and the respondeat superior standard of federal criminal liability. ${ }^{301}$ This focus is also consistent with arguments by U.S. scholars in favor of a standard such as corporate ethos. ${ }^{302}$

It is too soon to say whether the European initiatives will be successful in reducing or responding to corporate wrongdoing. Many of the provisions are relatively new, and we know little about their implementation. Moreover, Europeans are also developing new civil and administrative provisions, and we cannot predict which provisions will prove to be most useful. This leads us to one final observation. The notion of path dependence highlights the importance of the previous developments in each legal system, which set the stage for each subsequent set of reforms. ${ }^{303}$ For example, we noted above that many European nations lack some of the procedural and substantive legal provisions that make civil litigation an effective response to corporate behavior in the U.S. This distinction may explain why corporate criminal liability appears to be gaining favor in Europe, while in the U.S. its detractors argue in favor of civil remedies. The regulatory framework, the procedural rules, and the other remedies that are available vary from nation to nation. Those differences will play a role in determining the next steps that legal systems in Europe and in the U.S. will take to address corporate misconduct. We acknowledge that there

301. See supra notes 291,299 , and 300 .

302. See, e.g., Bucy, supra note 2, at 1099.

303. See Hathaway, supra note 254 , at 537-38. 
are also other significant factors our article does not discuss-including differences in the history, traditions, and social conditions of the various Western European countries-that have influenced and will continue to influence the development of the different standards of corporate criminal liability, or its absence, among those countries. We hope that further scholarship will shed light on those factors, while at the same time analyzing the continued development of the doctrines on which we have focused. 


\section{STANDARDS OF LIABILITY FOR CORPORATE CRIMINAL LIABILITY AMONG SELECTED WESTERN EUROPEAN NATIONS}

\begin{tabular}{|c|c|c|c|c|}
\hline Country & $\begin{array}{l}\text { Year Introduced and } \\
\text { Legislative } \\
\text { Codification }\end{array}$ & $\begin{array}{l}\text { Respondeat } \\
\text { Superior }\end{array}$ & $\begin{array}{l}\text { Management } \\
\text { and/or } \\
\text { Organizational } \\
\text { Failure }\end{array}$ & $\begin{array}{l}\text { Parallel } \\
\text { Individual } \\
\text { Liability } \\
\text { Available }\end{array}$ \\
\hline Denmark & $\begin{array}{l}\text { Limited introduction in } \\
\text { 1926, through passage } \\
\text { of the Butter Act; } \\
\text { uniform standard of } \\
\text { liability enacted in } 1996, \\
\text { as codified in section } \\
27(1) \text { of the Danish } \\
\text { criminal code; } \\
\text { comprehensive liability } \\
\text { on corporations enacted } \\
\text { in } 2002 \text {, as codified in } \\
\text { section } 306 \text { of the } \\
\text { Danish criminal code. }\end{array}$ & Yes & Yes & Yes \\
\hline Finland & $\begin{array}{l}1995 \text {, as codified in } \\
\text { chapter } 9 \text { of the revised } \\
\text { Finish penal code. }\end{array}$ & Yes & $\begin{array}{l}\text { Yes, when there } \\
\text { is no identifiable } \\
\text { culpable } \\
\text { individual }\end{array}$ & Yes \\
\hline France & $\begin{array}{l}1992 \text {, as codified in } \\
\text { article } 121-2 \text { of the new } \\
\text { French penal code }\end{array}$ & $\begin{array}{l}\text { Yes, but } \\
\text { generally } \\
\text { limited to } \\
\text { instances } \\
\text { where } \\
\text { corporate } \\
\text { officers and } \\
\text { directors are } \\
\text { personally } \\
\text { liable }\end{array}$ & $\begin{array}{l}\text { No (but note } \\
\text { expansion of } \\
\text { negligence-based } \\
\text { liability through } \\
\text { July } 2000 \\
\text { amendment of } \\
\text { article 121-3) }\end{array}$ & Yes \\
\hline $\begin{array}{l}\text { The } \\
\text { Netherlands }\end{array}$ & $\begin{array}{l}1976, \text { as codified in } \\
\text { paragraph } 51 \text { of the } \\
\text { Dutch penal code }\end{array}$ & Yes & Yes & Yes \\
\hline Switzerland & $\begin{array}{l}2003 \text {, as codified in } \\
\text { article } 100 \text { quater of the } \\
\text { Swiss criminal code }\end{array}$ & $\begin{array}{l}\text { Yes, but only } \\
\text { in cases of a } \\
\text { specific set of } \\
\text { serious } \\
\text { offenses when } \\
\text { corporation } \\
\text { cannot show } \\
\text { it took } \\
\text { reasonable } \\
\text { measures to } \\
\text { prevent } \\
\text { offense; } \\
\text { otherwise, } \\
\text { not available }\end{array}$ & Yes & $\begin{array}{l}\text { Yes, but } \\
\text { only in } \\
\text { cases of a } \\
\text { specific set } \\
\text { of serious } \\
\text { offenses; } \\
\text { otherwise, } \\
\text { availability } \\
\text { of } \\
\text { individual } \\
\text { liability } \\
\text { precludes } \\
\text { corporate } \\
\text { liability }\end{array}$ \\
\hline
\end{tabular}

